\title{
La situación de El Salvador: antecedentes, evolución y retos
}

\author{
La situación de El Salvador: antecedentes, evolución y retos ${ }^{1}$ \\ Héctor Dada Hirezi*
}

Recibido el 25 de septiembre de 2017, aceptado para su publicación el 20 de octubre de 2017

\section{Introducción}

Este trabajo forma parte de un proyecto de la Fundación Heinrich Böll titulado Análisis de la situación de El Salvador desde la perspectiva económico-social y política: Lectura de la coyuntura a partir de la historia de las últimas décadas. No está centrado en la presentación exhaustiva de cifras, sino más bien se trata de una interpretación cualitativa de la realidad coyuntural del país a partir de los cambios registrados en las tres últimas décadas; el énfasis estará en la lectura política de la situación nacional. Las estadísticas se utilizarán en la medida en que sirven de fundamento a determinadas afirmaciones, o que expresan numéricamente la realidad que se describe.

\section{Palabras claves}

El Salvador, acuerdos de paz, modelo neoliberal, remesas familiares, pobreza, estructura de la propiedad, alternancia política.

\begin{abstract}
This work presents a panorama of the reality of the country in the last decades. It is not focused on the exhaustive presentation of figures, but rather it is a qualitative interpretation of the country's conjunctural reality based on the changes registered in the last three decades; the emphasis will be on the political reading of the national situation. The statistics will be used to the extent that they help as a basis for certain statements, or that numerically express the reality that is described
\end{abstract}

1 Este documento ha sido elaborado para la Fundación Heinrich Böll. La responsabilidad del texto es exclusivamente del autor.

* Ingeniero civil y economista. hedadah@gmail.com 


\section{Key Words \\ El Salvador, peace agreements, neoliberal model, family remittances, poverty, property structure, political alternation.}

El responsable del trabajo es un profesional de las ciencias sociales, graduado en ciencias económicas. Como es obligado en este tipo de ciencias, el análisis estará influenciado por la escuela económica a la que me adscribo, lo que aparecerá a todo lo largo del texto. Se hace esta aclaración, dado que, con mucha frecuencia, no pocos colegas tienen la pretensión de hablar desde una postura supuestamente "técnica", neutra, y que responde a principios que son indiscutibles, posición que no se compadece con la naturaleza de las ciencias sociales.

Hemos adoptado una aproximación histórica. Los hechos del presente se explican en buena parte a través del análisis de los procesos en los cuales van surgiendo. Leer sólo los datos de la coyuntura permite una visión muy restrictiva de la realidad, más aún si esa lectura se reduce a relevar frías cifras sin ahondar en su significado y en su origen. De la presentación que se hace pareciera quedar claro que las decisiones económicas se toman en el espacio de la política, que es en el que corresponden, y no en el de la academia o en el de los técnicos.

En el Capítulo 1 se presenta brevemente algunos aspectos de la evolución histórica de El Salvador, que pueden ayudar a explicar la naturaleza de los conflictos que terminaron en una guerra civil larga y sangrienta. La concentración de los beneficios del desarrollo aparecerá como una constante, acompañada de exclusión socioeconómica y política.

En el segundo Capítulo se aborda la dualidad de procesos que abre la negociación final de la paz: la construcción de un sistema político democrático y la imposición de un modelo económico concentrador. En el siguiente se presentan los avances y las carencias de estos dos procesos, y la dinámica que abrió espacios a la alternancia política. En el cuarto se pasa a analizar los avances que permitió el cambio de grupo político en la conducción del gobierno, así como los estrechos espacios para realizar las reformas indispensables; se pone especial atención en la crisis fiscal que vive el país, en la que se expresan las dificultades políticas y económicas que caracterizan a El Salvador en este momento.

En el Capítulo cinco se intenta dar una reflexión sobre algunas líneas básicas que a mi juicio debe tener el abordaje de los retos centrales que enfrenta el país. La concreción de las respuestas surgirá de las correlaciones que se puedan construir en el proceso de discusión y de las alianzas sociales y políticas que se vayan produciendo.

Al final hemos colocado unas breves palabras en forma de conclusión. 


\section{Antecedentes históricos}

Tradicionalmente, la sociedad salvadoreña ha padecido de una profunda desigualdad. Heredada de la colonia, la república ha hecho muy pocos esfuerzos decididos para reducirla. En el siglo XIX, la puesta en el mercado de los colorantes sintéticos llevó a la casi total desaparición de la producción de tinturas a partir del índigo o añil, que era la actividad económica principal; en busca de un nuevo producto de exportación, la fuerza del Estado fue utilizada para expropiar las tierras de las comunidades - muchas de ellas indígenas - y de la Iglesia, para entregarlas a propietarios privados con el objetivo de que fueran dedicadas a la producción de café; desde las posiciones de control en el aparato del gobierno se determinó a quienes debían ser parte del nuevo sector cafetero que se convertiría en hegemónico, ejerciendo un patrimonialismo de Estado que ha sido una característica dominante de casi toda nuestra historia. La producción de café - destinado al mercado internacional - fue el eje de la economía salvadoreña hasta ya bien entrada la segunda mitad del siglo XX, y la principal organizadora de la estructura social y económica del país².

La Gran Depresión generó una brusca caída de los precios del café, con la consecuencia de graves problemas para la realización de la producción cafetera, y por ende sobre los ingresos de la oligarquía agraria y las posibilidades de trabajo remunerado para los trabajadores agrícolas, así como para las finanzas públicas y el comportamiento de la economía en general. Las demandas de la población no se hicieron esperar, y en diciembre de 1931 un golpe de Estado militar derroca al gobierno tímidamente reformista del Presidente Arturo Araujo; el control directo del aparato de Estado en manos de la oligarquía da paso al control indirecto a través de las Fuerzas Armadas, que duraría por casi medio siglo. En el año 1932 se dio una rebelión campesina - respaldada por el recién creado Partido Comunista Salvadoreño - en buena medida como consecuencia de los efectos de la Gran Depresión de la economía mundial sobre los precios del café; ella fue respondida con una defensa cerrada de la estructura de propiedad e ingresos existente a través de una dictadura sumamente represiva.

En $1948^{3}$, después de un golpe de Estado militar, se da un cambio de orientación, emprendiéndose un proceso de industrialización por sustitución de importaciones. Las políticas que se establecieron estaban basadas en la visión del Estado con responsabilidad social, reformas que sin embargo no afectaron esencialmente a la estructura básica de desigualdad en la distribución de ingresos y de propiedad;

2. El Informe de Desarrollo Humano El Salvador 2013 del PNUD hace una síntesis de la historia económica de El Salvador, y se presenta una extensa bibliografía.

3. Al inicio de la Guerra Fría los Estados Unidos de América presionaron por una "modernización" de los países centroamericanos, manteniendo el control militar del gobierno aunque realizando elecciones con resultados que en la mayoría de los casos estaban previamente garantizados. Como los mismos militares decían, no se podía permitir que la oposición democrática tuviera más espacios que los que la estabilidad del sistema toleraba. 
esto debido a la carencia de condiciones económicas y políticas para aliviar el carácter de eje central de la economía y de la estructura de la sociedad que tenía la propiedad de la tierra ${ }^{4}$. Utilizando como base los recursos provenientes de la agro-exportación para financiar al fisco, se estableció una política de apoyo estatal a los empresarios industrializantes, que incluyó carteras de crédito, altas protecciones arancelarias establecidas a nivel centroamericano, estímulos para las "industrias infantes", y un amplio programa de infraestructura vial y energética. Para aliviar la pequeñez de los mercados internos de la región originada en la demografía, y agravada por la desigual distribución de ingresos en 1960 se aprobó el Tratado General de Integración Económica Centroamericana que permitía la libre circulación de las producciones nacionales de los cinco países $^{5}$. Como resultado de esas políticas, la economía salvadoreña presentó tasas de crecimiento relativamente altas en la sexta $(4,7 \%)$ y séptima década $(5,6 \%)$ del siglo XX. Sin embargo, la desigualdad no presentaba tendencia a la reducción. Aún en 1970, la concentración de la tierra presentaba un valor del coeficiente de Gini de 0,83 , de los más altos del mundo6.

El conflicto bélico entre El Salvador y Honduras fue en parte consecuencia del desigual desarrollo que produjo la sustitución de importaciones a nivel de la región centroamericana, a la vez que fue una de las causas que aceleraron el debilitamiento de ese modelo. Al interior de la sociedad salvadoreña se produjo una situación en la que se combinaban conflictividades políticas con demandas sociales crecientes. Sucesivos gobiernos militares intentaron hacer reformas, que pronto se abandonaban para volver a favorecer los intereses de la elite agraria 7 . La convulsión social - que era contemporánea, y en buena medida relacionada, con sectores que habían elegido la vía armada para realizar la transformación de la sociedad - también estaba presente en otros países centroamericanos; en julio de 1979 la Revolución Sandinista asume el poder en Nicaragua, saliendo al exilio el General Anastasio Somoza Debayle, quien, además de tener el control total del aparato del Estado de su país, era un personaje con mucha influencia en los países centroamericanos que tenían gobiernos militares ${ }^{8}$. En octubre de

4. El gobierno del General Maximiliano Hernández Martínez creó el Banco Central de Reserva, el Banco Hipotecario de El Salvador, el Mejoramiento Social, que le dieron nuevos instrumentos de acción al Estado, utilizada para estabilizar dentro de la crisis la estructura económico-social del país. A partir de 1948 se estableció el seguro social para los trabajadores urbanos, una tímida política de distribución de tierras sin expropiación llamada colonización rural, mecanismos para utilizar parte del excedente de la agro-exportación para financiar al Estado y para proveer recursos para estimular la producción industrial, se creó el Instituto Regulador de Abastecimientos (IRA) para mitigar los vaivenes en los costos de reproducción de la fuerza de trabajo, se inició un intenso programa de obras públicas, etc. (Véase Dada Hirezi, H. [1978], y Turcios, R, [1993]).

5. Véase Dada Hirezi, H. (1978).

6. El dato aparece en Gordon, S., Crisis política y guerra en El Salvador, México, UNAM/Siglo XXI, 1989, citado por Acevedo, C. (2003).

7. Los intentos reformistas coincidieron frecuentemente con situaciones externas que hacían que los Estados Unidos de América consideraran necesario apoyar cambios. Desaparecida la coyuntura internacional que lo explicaba, el respaldo desaparecía y los gobiernos militares debilitaban su posibilidad de sacudirse el control oligárquico.

8. El único país de Centroamérica que tenía gobierno conducido por civiles era Costa Rica (Ver Torres Rivas, E. 2007) 
ese año el ejército salvadoreño da un golpe de Estado para cambiar la cúpula gubernamental, abriendo paso a un proceso de transformaciones en el país; la administración del gobierno es entregada a una Junta Revolucionaria de Gobierno (JRG), integrada por militares, y por civiles que habían trabajado por establecer un régimen democrático con relativa equidad. La Junta se comprometió a ejecutar un proyecto que ofrecía abrir espacio a la participación de todos los sectores en elecciones libres y equitativas, así como reformas profundas a la estructura de propiedad existente: reforma agraria, estatización de la banca y estricto control estatal del comercio exterior. Para la JRG el conjunto de reformas era un medio de encontrar caminos para evitar un conflicto armado abierto al eliminar las bases materiales del Estado oligárquico-militar, incorporar a los trabajadores agrarios a los beneficios del desarrollo, y abrir espacios a una economía fundamentada en la industrialización y con características más incluyentes ${ }^{9}$.

Bajo presiones de los Estados Unidos, y por desavenencias al interior del gobierno mismo, se dieron importante cambios en la composición de éste. El 6 de marzo de 1980 las mismas tres reformas fueron aprobadas por la renovada administración salvadoreña, pero esta vez como instrumentos de un plan de contrainsurgencia diseñado por autoridades de los Estados Unidos; su preocupación estaba centrada más en las consecuencias de un triunfo rebelde, en el contexto de la Guerra Fría, que en los problemas de la desigualdad ${ }^{10}$. El contexto político-militar en el que se diseñan y se ejecutan las reformas, no debe ser obstáculo para aceptar que generaron una profunda transformación de la estructura social y económica al expropiar ${ }^{11}$ buena parte de la propiedad agrícola y las instalaciones industriales dedicadas a la producción exportable, así como la banca comercial (que en

9. La discusión central en ese momento no estaba centrada en la indispensabilidad de hacer reformas, sino en el tipo de reformas y en sus objetivos. Obviamente continuaba habiendo grupos reacios a aceptar una salida reformista a la crisis, que consideraban que podía evitarse los cambios si se priorizaba la acción represiva sobre los insurgentes; consideraban a éstos como una fuerza controlada desde el exterior que no surgía de las realidades internas del país. La voz del Arzobispo de San Salvador Óscar Arnulfo Romero fue un respaldo importante para impulsar la idea del combate a la desigualdad: "Y si de justicia se trata y de encontrar las causas de nuestros males yo creo que el nuevo gobierno no debe parar hasta encontrar la última causa que está en la injusticia social" (Homilía del 25/11/1979). En definitiva, no es este el espacio para hacer un relato comprensivo sobre lo acaecido entonces. Hacemos una referencia muy sintética con el único propósito de darle marco a los temas que tienen relación con el objeto de este artículo.

10. Las reformas buscaban arrebatar a la oligarquía agrario-exportadora sus bases económicas de poder, a la vez que aislar a los trabajadores agrícolas de la influencia insurgente, con la visión de generar un "capitalismo moderno" después de la derrota de los alzados en armas. Hay que tener presente que en los estrategas estadounidenses dominaba la teoría del dominó - que coincidía con la visión que las autoridades cubanas tenían de la situación - que veía como posibilidad la caída progresiva de los países centroamericanos en manos de grupos de izquierda potencialmente aliados con la Unión Soviética a través de Cuba, en momentos muy álgidos de la guerra fría. Pese a la oposición de los sectores afectados, al aprobar una nueva constitución política en 1983 las restricciones a la posesión de la tierra fueron incluidas en su articulado con el voto unánime de todos los partidos legalizados, entre ellos el instituto político representante de los grupos empresariales ubicados más a la derecha (ARENA).

11. Las instalaciones agrícolas y financieras fueron tomadas en una operación militar, y las cooperativas agrarias que surgieron fueron puestas bajo supervisión político-militar por las autoridades del gobierno de facto. 
su mayoría estaba en manos de grandes terratenientes), al mismo tiempo que asumía el Estado el control del comercio exterior que era la fuente principal de la captación de excedentes de la elite dominante. La tierra requisada fue entregada casi de inmediato a cooperativas campesinas, en tanto la banca y las instalaciones agroindustriales fueron administradas por el aparato del Estado. Desde la segunda mitad del siglo XIX no se había dado una transformación de la estructura de propiedad como la que la contrainsurgencia produjo.

Mientras estas transformaciones se daban al interior de la economía salvadoreña, el mercado común centroamericano se vio muy debilitado por las conflictividades políticas regionales, la presencia distorsionante de potencias externas, y los problemas propiamente económicos unidos a las consecuencias económicas de los precedentes. La economía salvadoreña tuvo un decrecimiento de su producto interno, así como se volvió altamente dependiente de la "ayuda" estadounidense para solventar los compromisos financieros que originaba la guerra civil, y para mantener en funcionamiento la débil maquinaria estatal ${ }^{12}$.

Paralelamente, en el terreno político-institucional se realizaron transformaciones importantes. Ya en la década de los años 70 se habían iniciado movimientos insurgentes, que optaban por la vía armada para cambiar la estructura de poder económico y político del país; el golpe de Estado de 1979 no fue considerado por ellos como una forma de realizar las reformas adecuadas, sino más bien como una acción para cambiar sin verdaderamente hacer transformaciones sustanciales, con el objetivo de cerrarles espacios.

Ni la aprobación de las reformas contrainsurgentes el 6 de marzo de 1980 aisló a los insurgentes de sus bases, ni el asesinato de Monseñor Óscar Romero, el 24 de ese mismo mes, produjo la intimidación que buscaban los asesores contrainsurgentes y sus aliados de la derecha salvadoreña; este hecho, por el contrario, se convirtió en un detonante que catapultó la intensidad del conflicto social y de la guerra civil. En 1982, en pleno desarrollo del conflicto armado, se convocó a elecciones para establecer una asamblea nacional constituyente que restableciera la normalidad institucional. Los constituyentes declararon legal todo lo actuado por la Junta Revolucionaria de gobierno, y procedieron a nombrar un gobierno provisional "de unidad", que conformaron los partidos políticos con representación en la asamblea. Al siguiente año se aprobó la nueva Constitución Política, que utilizó como base el texto de la vigente al momento del golpe de Estado de octubre de 1979; las más notorias diferencias son, por una parte, la inclusión en el texto constitucional de los límites de propiedad de la ley de reforma agraria y, por otro lado, la eliminación de la prohibición de toda acción pública de las organizaciones

12. Que hubiera una alta dependencia política y financiera de los Estados Unidos de América no evitó diferentes discrepancias entre el gobierno demócrata-cristiano y las autoridades de ese país. Por ejemplo, éstas rechazaban los controles en el mercado de divisas que había definido El Salvador, así como sobre la amplia gama de productos cuyos precios eran regulados directa o indirectamente (ver Lindo F., H. en López Bernal, C. G. [2015]). 
de ideología "contraria a la democracia"13.

Para algunos de los que analizan ese período, las elecciones constituyentes fueron el inicio del proceso de institucionalización de la democracia en El Salvador; sin llegar a esa conclusión - que para otros puede ser extrema (yo me cuento entre éstos) - no puede negarse que comenzó a haber un respeto mayor a los resultados reales de las votaciones, que los que se habían dado en el tiempo del autoritarismo oligárquico militar; sin embargo, elecciones en situación de guerra, bajo vigilancia militar, y obviamente sin participación de los sectores políticos insurgentes y de los partidos no combatientes que estaban aliados con ellos ${ }^{14}$, sirvieron más para legalizar la contrainsurgencia, que para construir democracia. Lo que se generó fue una convivencia difícil entre instituciones electas de conformidad a un marco constitucional y obligadas a regirse por las normas legales, por un lado, y por el otro el control militar (de parte de las Fuerzas Armadas del país y de sus asesores estadounidenses) de las decisiones sobre la guerra, y de la represión contra los grupos y los ciudadanos que se consideraban enemigos del proceso sin someterse a las restricciones legales ${ }^{15}$.

Al asumir la presidencia de la República José Napoleón Duarte en 1984, demócrata cristiano, uno de sus objetivos fue intentar resolver la guerra civil por la vía del diálogo; el nuevo presidente pensó que tenía condiciones de diálogo que le permitirían llegar a un arreglo que acabara con el derramamiento de sangre, dado que fue el verdadero ganador de las elecciones de 1972, en las que contó con el respaldo del Partido Comunista Salvadoreño (PCS) ${ }^{16}$ y del Movimiento Nacional

13. El primer decreto de la Asamblea Constituyente fue la aceptación de la legalidad de los decretos de la Junta Revolucionaria de Gobierno, entre ellos los que afectaron la estructura de propiedad; además, se incluyó en el texto constitucional de 1983 la restricción a las extensiones de propiedad agraria en manos de privados que estableció la ley de la reforma agraria de 1980 (Art. 105). En el caso de las restricciones a la participación política, se eliminó el texto constitucional que la establecía, en buena medida como forma de invalidar el argumento de la insurgencia, que explicaba la opción de la vía armada a partir de las restricciones de participación en la política legal. En la práctica, más que la disposición constitucional, lo que estimuló la toma de esa opción fue el cierre de los espacios institucionales para acceder a la conducción del Órgano Ejecutivo por la negativa del régimen oligárquico-militar a reconocer los triunfos de la oposición política, así fuera democrática y de centro como el Partido Demócrata Cristiano (en Jerez, C. y Hernández Pico, J. [1973] se hace una descripción analítica del fraude electoral de 1972); en su discurso al firmar los acuerdos de paz en México, el Presidente Alfredo Cristiani reconoció que la inexistencia de espacios políticos fue una de las causas de la guerra (Véase Dada Hirezi, H. [2016]).

14. Nos referimos al Movimiento Nacional Revolucionario (MNR), miembro de la internacional social demócrata, a la Unión Democrática Nacionalista, cercano al Partido Comunista Salvadoreño (PCS, y al Movimiento Popular Social Cristiano (MPSC), una disidencia del Partido Demócrata Cristiano que no aceptó el plan contrainsurgente de diseño estadounidense.

15. El acto más conocido es el asesinato de Monseñor Óscar Arnulfo Romero en marzo de 1980, antes de la constitucionalización del proceso en 1983. Posteriormente, acciones no menos crueles se cometieron con diferentes ciudadanos, así como masacres de poblaciones civiles. Otra acción impactante, violatoria de toda norma legal - y por supuesto de todo respeto a la ética más elemental - fue el frío asesinato de los sacerdotes jesuitas y sus empleadas en 1989, al que se hará referencia más adelante.

16. El Partido Comunista Salvadoreño estaba en la ilegalidad; había penetrado a un partido legal llamado Unión Democrática Nacionalista (UDN), en que llegó a ejercer control. La UDN y el MNR 
Revolucionario, en ese momento integrados a la insurgencia. Al final de ese mismo año se realizaron las primeras conversaciones en La Palma, Chalatenango, en la que participaron dirigentes guerrilleros y junto a líderes de los partidos políticos que eran sus aliados. Los resultados no fueron coincidentes con las expectativas, $y$, lejos de resolver la confrontación, lo que se dio fue una intensificación de la guerra. Ni las condiciones internas, ni mucho menos los condicionantes que derivaban de la intensidad de la Guerra Fría en ese momento, permitían terminar con una guerra en la que los conductores de ambas partes estaban convencidos de que estaban ganando. Sin embargo, varios intentos posteriores fueron en buena medida fruto de la presión de una gran parte de la ciudadanía; ésta se movilizaba a favor de un acuerdo de paz, expresándose con el respaldo, y en cierta forma la conducción, de dirigentes religiosos católicos, protestantes y evangélicos pentecostalistas, entre los que destacaba el Arzobispo católico de San Salvador, Monseñor Arturo Rivera Damas, así como el sacerdote jesuita Ignacio Ellacuría.

En 1989 hubo elecciones presidenciales. Desde un año antes comenzó a negociarse la posibilidad de participación de los partidos miembros del FDR ${ }^{17}$. El Secretario del Movimiento Nacional Revolucionario, y dirigente de la Internacional Socialista, Guillermo Manuel Ungo fue el candidato. Por la derecha política y económica, representada en el partido Alianza Republicana Nacionalista (ARENA), el postulado fue un empresario, Alfredo Cristiani, luego de una fuerte presión de los estadounidenses para evitar que el candidato fuera el fundador del partido, mayor Roberto D’Aubuisson, ligado estrechamente a los excesos represivos desde los años setenta, primero como oficial de la Guardia Nacional, y en los 80 como líder de grupos irregulares de extrema derecha. El PDC lanzó al ministro de Relaciones Exteriores, el abogado empresarial Fidel Chávez Mena. La elección fue ganada por ARENA; la izquierda logró un magro resultado, lógico por las condiciones desfavorables en las que participó. Una derecha neoliberal, que había tenido una posición crítica al programa contrainsurgente de inspiración estadounidense, asumía el gobierno con un programa neoliberal diseñado por el centro de pensamiento de la empresa privada, que contaba con el respaldo político y financiero de los Estados Unidos ${ }^{18}$.

formaron una coalición con el Partido Demócrata Cristiano para respaldar la candidatura de Duarte en 1972. Un claro fraude electoral les arrebató el triunfo que habían obtenido en las urnas.

17. En esta decisión tuvo influencia el resultado de la reunión de presidentes centroamericanos llamada Esquipulas II, y que tuvo por objetivo establecer bases para la pacificación de la zona. Europa dio pleno respaldo a la iniciativa regional, que no era necesariamente coincidente con la visión del gobierno estadounidense. Eran momentos difíciles en la Unión Soviética, y los efectos de la acción de la "contra" en Nicaragua - conducida por los Estados Unidos - se sentían muy intensamente. No es éste el espacio para abundar sobre este tema.

18. En 1983, con pleno respaldo político de la Embajada de los Estados Unidos de América, y con financiamiento de la USAID, se creó la Fundación para el Desarrollo Económico y Social, (FUSADES), que contaba entre sus miembros a importantes empresarios y entre sus profesionales y técnicos a personas ligadas al sector empresarial. Se incorporaron en un inicio asesores chilenos, asesorados por el economista estadounidense de la escuela de Chicago, Arnold Harberger, que había estado involucrado con el programa económico de gobierno de Augusto Pinochet. Su objetivo era la promoción de las ideas de libre mercado, así como la elaboración de propuestas que pudieran orientar una transformación económica neoliberal al concluir el conflicto. Es obvio que el gobierno 
Si bien el cambio de orientación programática del gobierno es de gran importancia, no lo es menos lo que representa la negociación de la participación electoral de la izquierda dentro del proceso de diálogo para los acuerdos de paz. Se diga lo que se diga al respecto, es difícil dejar de lado que eso significaba, de parte de la insurgencia, la aceptación de la vía electoral como una posibilidad de buscar la conducción del gobierno, con la pluralidad política que una democracia requiere; y también, la implícita aceptación de la Constitución Política de 1983 como base de la organización institucional del Estado, hasta entonces considerada ilegítima por la insurgencia y sus aliados. Este cambio de actitud de los grupos insurgentes se ve más clara si consideramos que en enero de 1989 "el FMLN sorprendió al proponer la postergación de las elecciones presidenciales con el objeto de crear las condiciones que garantizaran una competencia democrática, comprometiéndose a respetar los resultados" (Turcios, R., en López Bernal, C. G. [2015] p. 117). Las posibilidades de avanzar hacia el fin del conflicto parecían crecer; lo que se vio confirmado con el discurso de Alfredo Cristiani al comenzar su gestión, en el que ofreció continuar con los diálogos existentes y ser un impulsor de un acuerdo de paz, como señalamos en la siguiente sección.

\section{Los acuerdos de paz y la imposición del modelo neoliberal}

La derecha al gobierno: diálogo, cambios constitucionales y reformas económicas

Alfredo Cristiani asumió la Presidencia de la República el 1 de junio de 1989. De su discurso inaugural podemos extraer dos temas que parecen ser los más importantes. Como se dijo arriba, hizo una oferta específica para continuar las negociaciones, respondiendo a las propuestas que antes y después de las elecciones le había presentado la alianza FMLN- FDR al gobierno de Napoleón Duarte; sus palabras contradecían la posición de rechazo que la derecha había asumido frente a las reuniones que se habían llevado a cabo durante el gobierno que terminaba. Si la insurgencia hablaba de negociación, el nuevo Presidente mencionaba sólo la palaba diálogo, por la interpretación que la derecha había dado a ese término: negociar es discutir la posibilidad de compartir el poder. El diálogo, dijo el empresario-presidente, debe ser serio, permanente y reservado, entre "el sector democrático y el FMLN", concibiendo al primero como los partidos que en ese momento tenían representación parlamentaria. Para su realización, el gobierno establecería una comisión de "personalidades democráticas" para constituir un organismo de trabajo con una contraparte que solicitaba a la insurgencia que constituyera; este organismo sería el encargado de trabajar en la elaboración de propuestas, y se comprometía a que una vez iniciado el diálogo la comisión del gobierno no se levantaría de la mesa "hasta que no se presente a los organismos de la más alta decisión política un planteamiento de solución

de Ronald Reagan, y su sucesor George Bush, respaldaron el reformismo contrainsurgente por razones de estrategia de guerra, dado que el Estado interventor que implicaba era contrario a su tesis de Estado mínimo; simultáneamente preparaban las condiciones para que en El Salvador se impusiera, llegada la ocasión, una visión de desarrollo más acorde con el pensamiento dominante en los Estados Unidos. 
global al conflicto". El proceso, decía el Presidente, debía llevarse a cabo en el exterior, mientras ofrecía mantener "constantes consultas" con los partidos políticos legales.

El segundo tema que se resalta es la visión del desarrollo económico que dijo tendría su gobierno. Coherente con la línea de pensamiento de FUSADES, y de sus asesores de la Escuela de Chicago, limitó al Estado a ser "regulador de las normas indispensables para que la economía funcione, reduciendo el papel del Estado a lo estrictamente necesario", rechazando toda idea de Estado "dirigista o interventor", que incursionara en espacios en los que debe actuar el mercado, y que pudiera "distribuir los recursos, y la asignación de prebendas y privilegios discrecionales". El Estado "interventor", que había estado presente desde décadas atrás, y que fue un instrumento para desarrollar el "modelo de industrialización por sustitución de importaciones"19, había sido reforzado por la aplicación de las reformas contrainsurgentes diseñadas por los funcionarios estadounidenses; ahora se daba una vuelta de timón, pues se consideró que había llegado la hora de aplicar las ideas y propuestas que se habían elaborado en FUSADES ${ }^{20}$.

Las condiciones internacionales e internas daban marco al discurso de Cristiani, y a la posibilidad de llevar adelante sus objetivos. La Guerra Fría se vislumbraba en sus últimos días; la Unión Soviética y los Estados Unidos habían iniciado los esfuerzos para lograr una détente. El Consejo de Seguridad de la ONU daba instrucciones al Secretario General para actuar en la búsqueda de la paz en la región. La ofensiva "hasta el tope", que realizó el FMLN en noviembre de 1989, fue su mayor demostración de poder militar. Si bien pareció haber alejado las posibilidades de obtener un acuerdo, lo que sucedió fue lo contrario: al mostrarse claramente los costos de buscar un triunfo militar por cualquiera de las partes - inaceptables para la sociedad salvadoreña, lo mismo que para los actores internacionales en una coyuntura mundial signada por la fractura del mundo del "socialismo real" - se generó un fuerte impulso a la demanda del cese del conflicto. La masacre realizada en la UCA por el ejército en medio de la ofensiva (16 de noviembre), en la que asesinó a seis sacerdotes jesuitas y a dos empleadas, si bien se hizo para afectar las correlaciones en el proceso de negociación, en la práctica fue un detonador de presiones pacificadoras y debilitó a los sectores más duros de la derecha ${ }^{21}$. Las partes asumieron con más intensidad que nunca la tarea de elaborar una propuesta de solución al conflicto, con la mediación de la Organización de Naciones Unidas.

El escenario nacional facilitó la iniciación de la aplicación de las medidas

19. La Constitución Política de 1950 daba al Estado funciones en el área económica, de conformidad a las visiones de la época. Las constituciones de 1962 y 1983 mantuvieron estas funciones, acrecentadas en esta última con las restricciones a la propiedad que se menciona adelante.

20. Ver nota anterior. Las propuestas mencionadas aparecen en FUSADES (1989).

21. En Villiers Negroponte, D. (2012) puede encontrarse una descripción de las conversaciones entre soviéticos y estadounidenses, y de cómo veían desde Washington la situación de Centroamérica y en específico de El Salvador. 
económicas. Con la atención del país puesta en la posibilidad de realización de la esperanza del fin de la guerra civil, el proyecto de cambios comenzó a realizarse rápidamente, aprovechando también que las elecciones legislativas de 1988, y las presidenciales de 1989, le habían dejado a ARENA la posibilidad de controlar todos los órganos del Estado. El modelo coincidía con las propuestas fundamentales de lo que se llamó "Consenso de Washington", con su exacerbado individualismo como línea orientadora. En una síntesis apretada, éstas eran sus características ${ }^{22}$ : a) apertura económica, tanto respecto al mercado exterior, como a la eliminación de las restricciones de precios y de los espacios de la libre actividad empresarial; estas medidas permitirían un aumento de la competitividad de los sectores en los que se tenían ventajas comparativas, con las consecuentes mejoras en la productividad, y posibilitarían al país tener a las exportaciones como su principal factor de crecimiento ${ }^{23}$; b) aprovechamiento de la ventaja comparativa que representa la relativa abundancia de fuerza de trabajo; c) la privatización de los activos productivos en manos del Estado (bancos, ingenios azucareros, beneficios de café, distribuidoras de electricidad y empresas de telecomunicaciones) ${ }^{24}$; d) en la lógica de favorecer la concentración de los excedentes para estimular la inversión, se reducirían las tasas marginales superiores del impuesto a la renta, así como se eliminarían los impuestos a la propiedad y a la herencia ${ }^{25}$; e) como contrapartida, se convertiría al impuesto al valor agregado (IVA), que pagan los consumidores, como la base principal de recaudación de recursos fiscales; f) la regla de subir los salarios para compensar la inflación, debía ser sustituida por la de ajustar los salarios de conformidad a la productividad. La norma era: al mercado - entiéndase al sector privado - todo lo que sea posible; el Estado no puede ser parte de la solución porque es el problema, para utilizar la frase del Presidente de los Estados Unidos Ronald Reagan.

Las instituciones financieras internacionales, así como el gobierno de los Estados Unidos, apoyaron decididamente las reformas neoliberales; lo que era normal, dado que el llamado Consenso de Washington era la confluencia del pensamiento de base en el FMI, en el Banco Mundial, y en el BID, que a la vez coincidía con la dominación de la Escuela de Chicago en la visión de ese gobierno. Asesores y recomendaciones respaldaban al gobierno salvadoreño. El historiador económico

22. Reiteramos que no es nuestro objetivo hacer un análisis completo de las medidas tomadas, sino sólo dar un marco para desarrollar el objeto de este trabajo. Hay diversos trabajos que describen este período. Véase, por ejemplo: Rivera Campos, R., (2002); PNUD (2013) sección 3; Dada H., H. (2015b, 2013); Acevedo, C. (2003).

23. En el modelo de sustitución de importaciones el espacio privilegiado de expansión de las exportaciones era el Mercado Común Centroamericano; en este modelo, es el mercado mundial. Para algunos asesores externos la integración centroamericana había muerto.

24. Más adelante se pasó de un sistema de reparto a uno de ahorro individual para la prestación social de las pensiones de jubilación y se intentó privatizar la parte de salud del Instituto Salvadoreño del Seguro Social (ISSS).

25. Desde entonces la empresa privada argumenta que todo impuesto que deba pagar la empresa o que tase las rentas de sus propietarios desestimula la inversión, y por ende el crecimiento y la generación de empleo. 
salvadoreño Héctor Lindo lo dice con gran claridad: “Las autoridades salvadoreñas eran particularmente propensas a recibir la asesoría de expertos internacionales debido a la magnitud de los niveles de ayuda que recibió el país durante la guerra y el apoyo que los organismos internacionales estaban dispuestos a prestar en la tarea de reconstrucción de la posguerra. Una de las primeras responsabilidades importantes que adquirió la administración de Cristiani fue un préstamo del Fondo Monetario Internacional que comprometía a ajustes estructurales" (López Bernal, C. G. [2013], p. 257). Yo agregaría que la conversión de las medidas de ajuste en compromisos con el FMI, lejos de ser una imposición del organismo, fue firmada para volverlas responsabilidades contractuales; al fin y al cabo ellas estaban presentes en las propuestas de FUSADES, que habían sido elaboradas a partir de la misma línea de pensamiento, con asesoramiento externo y ayuda financiera de USAID, en momentos en los que Cristiani era directivo de la institución.

En plazo muy corto comenzó el proceso de abrir la economía al mercado exterior, en este caso a través de decisiones de los organismos intergubernamentales centroamericanos. Se estableció un nuevo Código Aduanero Centroamericano que desmontaba la protección al mercado regional, pasando los aranceles de un rango de 290-0 a uno de 20-526. Si el Mercado Común suponía una política de fomento a la exportación de productos industriales a las economías de los países socios, ahora la apuesta era abrirse al mundo para exportar al mercado internacional, y obligar a las empresas internas a competir sin las altas barreras del pasado. Se derogaron los impuestos a la exportación de bienes agroindustriales, los cuales hasta entonces habían sido la base de ingresos del fisco ${ }^{27}$. Se eliminaron las normas y las instituciones que regulaban los precios, así como los organismos estatales encargados de canalizar las agro-exportaciones. Se procedió a la imposición del impuesto al valor agregado (IVA), estableciendo una tasa de 11\%. Más adelante, ya con posterioridad a los Acuerdos de Paz, se pasó a aplicar las medidas de reducción o eliminación de los impuestos directos mencionados arriba. Más que reducir la inequidad de la política tributaria, las medidas profundizaron su regresividad, absolutamente coherente con su filosofía de concentrar inicialmente para que a través de la inversión y la producción de empleos el bienestar descienda a la mayoría.

En el año 1991 se inició la privatización de los activos productivos del estado, iniciando con los que habían pasado a ser propiedad pública a través de las expropiaciones del reformismo contrainsurgente. Las instituciones del sistema

\footnotetext{
26. A partir de la firma en 1993 del Protocolo de Guatemala, que reformó al Tratado General de Integración Económica Centroamericana. Así se concluía la adaptación del acuerdo de libre comercio regional a la nueva visión aperturista, eliminando completamente el modelo de sustitución de importaciones con el que había sido concebido. Las dos cifras menores de los rangos de aranceles corresponden a bienes de capital y a insumos para la producción.

27. Estos aranceles no estaban regulados por los acuerdos de la integración regional, sino por la legislación interna.
} 
financiero ${ }^{28}$ fueron las primeras en pasar a manos privadas en un proceso poco transparente, controlado desde las autoridades del gobierno ${ }^{29}$. Así se conformó desde el aparato del Estado la nueva elite económica que centraría su poder primordialmente en el control de dicho sistema. Después se iba a concretar el traslado a manos privadas de los ingenios azucareros y los beneficios de café, confiscados en 1980, así como de los monopolios estatales en comunicaciones y distribución eléctrica. En estos casos, se afirmaba que se eliminaba el monopolio estatal en el sector, con el objetivo de generar competencia; sin embargo, en los hechos se tiene un mercado monopolístico, con alta concentración. En lo que respecta a la producción de electricidad se dejó en manos del Estado buena parte de la producción ${ }^{30}$, esencialmente la que utiliza recursos hidráulicos, con apertura a inversiones privadas. También se privatizaron otras actividades económicas que estaban en manos del Estado, algunas con anterioridad a 1980, como zonas francas, plantas de alcohol, etc.

La reforma agraria no fue revertida. No se estableció legalmente ninguna medida para cambiar el estatuto de propiedad colectiva de las tierras en las empresas cooperativas. La imposibilidad política de tomar esas medidas impedía que se actuara directamente contra una forma de posesión que contrariaba los fundamentos del modelo. Lo que se hizo fue debilitar, hasta la casi desaparición, el compromiso del gobierno con el éxito de las cooperativas ${ }^{31}$. Las excepciones no eliminan la posibilidad de calificar a las privatizaciones realizadas por los gobiernos de ARENA como la segunda reforma fundamental de la propiedad y por consecuencia de la estructura de la sociedad - en un poco más de dos décadas.

Entre 1991 y 1995 la política aplicada pareció lograr éxitos, pues el PIB creció a una tasa media de 6,5\% entre 1991 y 1995. Sin embargo, contra las expectativas de los creadores del modelo, lo que se produjo fue principalmente el efecto de lo que algunos economistas llaman "efecto rebote" (la satisfacción de demandas de consumo e inversión pospuestas durante el conflicto), a la vez que de la utilización de una importante cantidad de recursos fiscales y de ayuda externa

28. En 1990 la Asamblea Legislativa aprobó la Ley de Privatización de los Bancos Comerciales y de las Asociaciones de Ahorro y Préstamo. Se procedió a limpiar las carteras financieras de los bancos, previamente al traslado de la propiedad a manos privadas, que se inició el 1991.

29. Juan Héctor Vidal describe las disposiciones legales que debían normar el proceso de privatización del sector financiero, así como la forma en que se hizo, en su libro De la ilusión al desencanto (Vidal, J. H. [2010], p. 207 y s.)

30. Más adelante pareció que se tenía la intención de proceder a la privatización de todo el sector de producción de electricidad, pero no se dieron pasos claros en esa dirección.

31. Las cooperativas fueron asistidas durante la guerra con recursos de USAID primordialmente, pero en ningún momento - por razones de la lógica de control de la insurgencia - se estimuló adecuadamente su capacidad de producción y organización empresarial para que lograran independencia económica. Más bien se veía como una medida social el respaldo que se les daba, y a las cooperativas de la reforma agraria se les consideraba - y en buena medida se sigue haciendo - como movimientos sociales, y no como empresas de propiedad social. 
para la reconstrucción ${ }^{32}$. Debilitados estos factores, la economía salvadoreña vio descender rápidamente la velocidad del incremento de su actividad, y entró en un período largo de lento crecimiento que se mantiene hasta ahora ${ }^{33}$, y al que nos referiremos más adelante.

\section{Los acuerdos de paz.}

En tanto, el gobierno del Presidente Cristiani retomaba el control del aparato del Estado para la derecha empresarial y política - es difícil establecer fronteras entre ellas - las negociaciones de paz continuaban avanzando. Hay toda una diversidad de convenios previos al documento final, entre los que, a partir de los objetivos de este trabajo, podemos resaltar el tema relativo a las reformas a la Constitución Política de 1983 que se hicieron en 1991. Para la insurgencia, había cambios a la ley primaria que eran indispensables para abrir espacio a la consecución del fin del conflicto: eliminar el papel tutelar sobre el sistema democrático que en última instancia se le concedía a la Fuerza Armada - heredado de la época de los gobiernos militares con elecciones que habían dominado nuestra vida política ${ }^{34}$ - limitando sus funciones a ser garante de la seguridad nacional, y con posibilidad de recibir atribuciones limitadas y temporales en la seguridad pública; establecimiento de mecanismos de control de los procesos electorales por parte de los partidos políticos contendientes, para buscar mayor garantía en el respeto a los resultados; formas de elección más transparente y participativa de los funcionarios de elección de segundo grado (Corte Suprema de Justicia, Fiscal General de la República, y varios más). Aprobados los cambios en la Asamblea Legislativa ${ }^{35}$, la ruta hacia un acuerdo definitivo se volvió casi imparable, pese a resistencias de los sectores más duros de la derecha. El 31 de diciembre se terminó de definir el texto final de los Acuerdos de Paz, y el 16 de enero de 1992 se procedió a su firma en el castillo de Chapultepec, en México, con la presencia del Secretario General de la ONU, y un número importante de Jefes de Estado y de gobierno.

Para Roberto Turcios, lo que se había dado debía calificarse como “la negociación

32. Según Juan Héctor Vidal, en ese momento Director Ejecutivo de ANEP, "lo que realmente preocupaba a los empresarios era que no se estaba logrando el objetivo central de hacer de las exportaciones el eje de crecimiento, como postulaba el modelo" (Vidal, J. H. [2010], p. 380, nota 304)

33. En diversas ocasiones y documentos, instituciones financieras internacionales han expresado que la tasa de crecimiento esperado de El Salvador es alrededor del 2\%. Las tasas corresponden al crecimiento a precios constantes.

34. En la lógica de lo que los teóricos de la "seguridad nacional" llamaban democracias limitadas, y que fueron apoyadas por los Estados unidos en el marco de la Guerra Fría, como se expresó en el acápite anterior.

35. Los partidos políticos miembros del FDR habían participado en las elecciones legislativas de ese año en una coalición llamada Convergencia Democrática, en la que lograron una bancada minoritaria. Participaron activamente en el impulso a la segunda aprobación del proyecto de reformas constitucionales, luego que la asamblea saliente les había dado su primera aprobación el último día de sus funciones. 
para un pacto transicional", dado que "dio un vuelco a la historia política salvadoreña. Sobre la secuela todavía humeante de la guerra emergía la coexistencia pluralista de todos los bloques políticos sociales, incluidos los que se enfrentaron con armas durante una década" (en López Bernal, C. G. [2015], p. 118). La visión de Turcios ya estaba presente en el discurso de Cristiani en la ceremonia de firma del documento de la paz: "Nos quedaríamos injustamente cortos si viéramos sólo hacia el pasado inmediato para medir la magnitud de lo que ocurre en El Salvador de un tiempo a esta parte. La crisis en que se vio envuelta la nación salvadoreña en el último decenio no surgió de la nada, ni fue producto de voluntades aisladas. Esta crisis tan dolorosa y trágica tiene antiguas y profundas raíces sociales, políticas, económicas y culturales en el pasado. Una de las perniciosas fallas de nuestro esquema de vida nacional fue la inexistencia de los espacios y mecanismos necesarios para permitir el libre juego de las ideas, el desenvolvimiento natural de distintos proyectos políticos derivados de la libertad de pensamiento y acción. En síntesis, la ausencia de un verdadero esquema de vida democrático. La crisis profunda hizo surgir la posibilidad real de la democracia en nuestro país (...)" (Cristiani, A. [1992] p. 1-2]).

El texto del acuerdo firmado incluía disposiciones sobre temas como el asentamiento de los combatientes guerrilleros, la depuración de la Fuerza Armada, la creación de una Comisión de la Verdad que investigara los crímenes cometidos durante la guerra. La supervisión de los acuerdos se delegó en la ONU, que estableció una oficina especial en San Salvador y garantizó que los convenios fueran cumplidos de una manera muy satisfactoria, pese a conflictos menores.

Hay que hacer notar que, durante las negociaciones, el modelo de desarrollo impuesto por el gobierno del Presidente Cristiani no fue puesto en cuestión. Las referencias a lo económico se reducen a disposiciones para entregar tierras y reparaciones monetarias a los combatientes de ambos bandos; para discutir cuestiones de política económica y social se creó el llamado Foro para la Concertación Económica y Social, que tuvo vida efímera, sin lograr mayores resultados ${ }^{36}$.

36. Diversos estudiosos del proceso de paz afirman que aprovechando el ambiente electoral previo a las elecciones, el gobierno, de acuerdo con la empresa privada, argumentó que debían suspenderse las reuniones para que no se contaminaran de la disputa partidaria, para reiniciarlas después; esto no se hizo. Vidal da una versión matizada de los sucedido: "Ciertamente, esta instancia no rindió los frutos esperados, en parte por la renuencia del gobierno de turno - más allá de las declaraciones públicas - de abrir efectivamente los espacios para el diálogo alrededor de los temas económicos y sociales, acaso bajo la presión de los poderes fácticos que siempre han actuado al margen de las organizaciones formales de la empresa privada" (Vidal, J. H. [2010], p. 410). No es el único caso en el que puede observarse, o al menos sospecharse, que hay indicios para creer que los miembros de la elite económica con mayor poder actúan al margen o en contra de lo que las gremiales deciden. 


\section{El avance democrático y el agotamiento del modelo económico La institucionalización de la democracia electoral}

Con activa participación de la Misión de la Organización de Naciones Unidas para El Salvador (ONUSAL) se fueron implementando las disposiciones de los Acuerdos de Paz. Pese a problemas en la ejecución, es generalizada la idea de que el proceso fue casi ejemplar. Se respetó escrupulosamente el cese al fuego, los insurgente pudieron volver al país y gozar de sus derechos ciudadanos, y el FMLN fue convertido en partido político a través de un decreto legislativo. Una Comisión de la Verdad, integrada por personalidades extranjeras, realizó la investigación de los crímenes de guerra, y dio su informe a la sociedad ${ }^{37}$. Una Comisión Ad Hoc, integrada por personalidades nacionales, procedió a analizar el comportamiento de los oficiales de las Fuerzas Armadas en materia de respeto a las normas de la guerra, y recomendó la salida de más de un centenar de ellos, lo que fue acatado por el gobierno civil y el alto mando militar. La convivencia pacífica se abría paso dejando atrás los altos niveles de violencia que se vivían.

La situación no sólo requería el abandono de cualquier espíritu de venganza por parte de quienes habían sido afectados por la violencia. También exigió cambios fundamentales en los dos agrupamientos que desde entonces dominarían la vida política nacional. Para el FMLN significaba abandonar la idea de establecer la "dictadura del proletariado" (lo que parecería que ya había hecho con su actitud frente a las elecciones de 1989) y dejar de ser un grupo político armado, convirtiéndose en un partido legal compitiendo en elecciones plurales. Para ARENA (nacido en 1981 con un componente armado a través de los llamados escuadrones de la muerte), la exigencia fue la superación de su visión de exclusión política y eliminación de los "rojos", y también debía abandonar sus componentes paramilitares. Las elecciones de 1994 serían la primera gran prueba que tendría la nueva realidad política; en ellas se disputaban la presidencia, la Asamblea Legislativa, y los concejos municipales, es decir la totalidad de los puestos de elección por votación directa de la ciudadanía. Éstas eran las primeras elecciones después de los acuerdos, y las primeras en las que el FMLN competía; fueron llamadas “las elecciones del siglo”. Según Roberto Turcios: “La alusión al siglo era exagerada, aunque tenía cierta razón porque entonces comenzaba el cómputo de otro siglo político y la configuración de otro modo de desarrollo" (López Bernal, C. G. [2015] p. 121).

Las elecciones fueron ganadas ampliamente por ARENA, que además de la presidencia de la República obtuvo control de la Asamblea Legislativa y de la mayoría de los concejos municipales del país. El FMLN, por su parte, logró el segundo lugar, desplazando al tercero al Partido Demócrata Cristiano, y así tuvo

37. La respuesta del gobierno fue hacer aprobar por la Asamblea Legislativa una ley de amnistía total por los crímenes de guerra, que eliminó la posibilidad de establecer sanciones penales o restricciones de los derechos políticos como recomendaba la Comisión de la Verdad para algunos casos. La Corte Suprema de Justicia declaró inconstitucional esa ley hace unos meses. 
la posibilidad de participar en la segunda vuelta de la elección presidencial, y obtener una numerosa bancada de diputados y el gobierno de un número nada despreciable de municipios. La organización política armada se convertía en un partido político dentro de la legalidad institucional, con ejercicio de funciones en diversas instancias del Estado, y en un instrumento para canalizar - ante las instituciones del aparato del Estado - las demandas de los sectores de población que asumía representar. El espacio político-institucional se convertía en el centro de la disputa, dejando definitivamente en el pasado a la vía armada como instrumento de lucha política.

Desde entonces el aspecto electoral de la democracia ha avanzado de forma innegable. Los resultados electorales siguieron siendo respetados en múltiples elecciones posteriores a las “del siglo": cuatro presidenciales (1999, 2004, 2009, 2014) y siete legislativas y municipales (1997, 2000, 2003, 2006, 2009, 2012). El partido ARENA volvió a ganar el órgano ejecutivo en las elecciones presidenciales de 1999 y 2004, lo que le permitió gobernar por veinte años consecutivos; en esas dos décadas pudo obtener mayorías propias, llegar a arreglos con otros partidos, y en ciertos casos lograr disidencias del FMLN, para tener control del órgano legislativo; así pudo manejar con relativa libertad las elecciones de segundo grado $^{38}$. Su capacidad de controlar los tres órganos del Estado y buena parte de otras instancias del aparato estatal le permitieron imponer sus políticas con muy pocas restricciones ${ }^{39}$.

En 1997 el resultado de las elecciones municipales fue más favorable a la izquierda que las de tres años atrás. Entre sus éxitos puede señalarse uno muy simbólico, como es haber obtenido el control del gobierno municipal de la capital gracias a una alianza con algunos partidos, pero en especial con un grupo cívico-político, siendo éste el que mayor número de miembros tuvo en el Concejo Municipal presidido por Héctor Silva, ex-militante del Movimiento Popular Social Cristiano ${ }^{40}$. Si bien este triunfo fue acompañado por otros en ciudades importantes del país, dada la relevancia política del gobierno de San Salvador, y la presencia mediática que tiene, se convirtió en la muestra de la integración del FMLN a la institucionalidad democrática, y abría la percepción de la posibilidad de obtener, en un futuro no muy lejano, el control del órgano ejecutivo.

\footnotetext{
38. Los más importantes son: los magistrados de la Corte Suprema de Justicia y de la Corte de Cuentas, el Fiscal General de la República; el Consejo Nacional de la Judicatura.

39. El los dos últimos períodos hubo algunos lapsos en este control, pero sin consecuencias mayores en su relativa libertad para poner en marcha proyectos de ley para hacer avanzar sus apuestas. En los casos más notorios, los obstáculos vinieron más de las organizaciones sociales y de la movilización de la ciudadanía. El más importante se dio durante el tercer gobierno de ARENA, presidido por Francisco Flores, cuando se intentó privatizar los servicios de salud del Instituto Salvadoreño del Seguro Social.

40. El Movimiento Popular Social Cristiano, como dijimos antes, fue una disidencia del Partido Demócrata Cristiano, surgido en 1980, y posteriormente integrado al Frente Democrático Revolucionario.
} 


\section{Visión patrimonial de la función pública}

La presencia de empresarios en puestos gubernamentales y en cargos partidarios fue frecuente en los gobiernos de ARENA, así como de ejecutivos o asesores económicos y jurídicos del sector empresarial. No pocas veces alternaban el servicio en cargos públicos, con trabajo partidario, o con cargos directivos o ejecutivos de las gremiales o de empresas privadas, o en su llamado "tanque de pensamiento", FUSADES. Citando de nuevo a Turcios, él hace sobre esta realidad la siguiente observación que se refiere a la privatización de la banca: "El hecho de que los bancos funcionaran con eficiencia bajo las nuevas administraciones, en cambio, nunca lograría disipar la sospecha de que la transferencia había sido un mecanismo novedoso de concentración de un reducido número de empresarios, entre ellos titulares del poder público" (en López Bernal, C.G. [2015] p. 122). El economista Juan Héctor Vidal, que en un tiempo fue director Ejecutivo de la Asociación Nacional de la Empresa Privada (ANEP), lo dice con la misma claridad: "Se puede colegir entonces que el origen de las anomalías mencionadas no estuvo tanto en la ley ${ }^{41}$, cuanto en la falta de cumplimiento de la misma y el mero hecho de que el presidente del BCR y el mismo presidente de la República, aparecieran eventualmente como los principales accionistas de los bancos más grandes, a través de grupos en los que ya tenían fuertes intereses." (Vidal, J. H, [2010] p. 214). La utilización del aparato del Estado de forma patrimonial fue una característica de los cuatro gobiernos del partido de la derecha.

\section{Objetivos y resultados del modelo económico}

Los objetivos que inicialmente se planteó la derecha, no pudieron ser logrados, aun cuando contó con veinte años de gobierno continuo, y pese a los estímulos concedidos a la inversión, al manejo empresarial de la función pública, a la pacificación de las relaciones partidarias, al respaldo externo a la implementación del modelo. Se quería pasar a ser un país con una balanza comercial positiva, y sin embargo, rápidamente se registró un déficit comercial creciente (llegó una cifra de alrededor del 20\% del PIB en el período 2004-2008); aun con la entrega de activos estatales al sector privado, y con una generosa política de reducción impositiva y de estímulos para la producción - los cuáles sí produjeron la deseada concentración - la inversión privada se mantiene en bajos niveles; la primacía del consumo y de la importación en la determinación del comportamiento económico ha sido la regla desde entonces; etcétera. 
En tanto, las oportunidades de ocupación con ingresos dignos no llegaron a cristalizarse ${ }^{42}$, lo que ocasionó que para una buena cantidad de salvadoreños se fueran desvaneciendo las esperanzas y las expectativas de mejorar su situación; la emigración - que se había iniciado en menor medida en las décadas anteriores - representó el camino que anualmente toman decenas de miles de salvadoreños buscando las oportunidades que no encuentran en su país. Las remesas que los migrantes envían a sus familias se convirtieron en un importante ingreso de divisas que sirve para paliar los problemas de la balanza de pagos, a la vez que pasaron a tener un importante papel como instrumento para respaldar el consumo, y a través de la circulación dinamizan la economía en su conjunto. En la práctica se pasó, como dice el PNUD, a un "modelo consumista de promoción de importaciones y exportación de mano de obra” (PNUD, [2013) p. 95) ${ }^{43}$. Más importante aún, las remesas familiares ${ }^{44}$ se convirtieron en una suerte de política social privada - transferencias de recursos de los salvadoreños residentes en el exterior para subsidiar a sus familiares residentes en el territorio nacional - que enfrenta los problemas de la pobreza y de la desigualdad con más recursos que cualquier acción del Estado en ese campo. Su monto ha alcanzado una media superior al 16\% del PIB en el período 2010-2015, equivalente a un alto porcentaje de los ingresos fiscales y del monto de las exportaciones, es varias veces el valor de las inversiones extranjeras directas, y supera ampliamente al gasto social del gobierno. No puede ignorarse que los que deciden emigrar son muchas veces aquellos que están dispuestos al trabajo y al cambio, cualidades necesarias para un proceso de transformación productiva del país.

\section{El surgimiento de la violencia de las pandillas}

Haciendo una digresión para abordar un tema no estrictamente económico, pero muy importante para todas las esferas de la vida nacional. Al llegar el cese del conflicto armado, a partir de la concepción extrema sobre el papel del mercado gran organizador, no se visualizó el necesario papel del Estado en la reconstitución del tejido social que exigía la situación posconflicto; la guerra generó movimientos poblacionales que afectaron las estructuras de convivencia social, ya fuertemente alteradas por los cambios producidos por las reformas a la propiedad realizadas en 1980. Si bien se hicieron políticas de asistencialismo social, no se cumplió con la responsabilidad de asumir tareas en la realidad concreta de los territorios para generar un nuevo tejido social capaz de normalizar las relaciones. El rápido incremento de la "tugurización” de buena parte de la

42. Menos de la mitad de la población tiene empleo en el sector formal, y sólo una cuarta parte tiene seguridad social.

43. El crédito al consumo ha tenido un papel coadyuvante en el impulso al modelo señalado por el PNUD.

44. La Secretaría de la Integración Social Centroamericana publicó en un libro las ponencias presentadas en el seminario que patrocinó en 2013, bajo el título Migraciones y mercados laborales en Centroamérica (San Salvador, SISCA-OCADES, 2013); en él está incluido nuestro trabajo "Migración intrarregional y mercados laborales en Centroamérica: desafíos para la integración”. 
población, en asentamientos sin propiedad legal, sólo fue respondido con un programa de legalización de tierras que se mostró insuficiente al abordar sólo un aspecto del problema. Las migraciones hicieron que muchas familias tuvieran una estructura extendida geográficamente; sus miembros que permanecían en el país tienden a depender más de los recursos recibidos de sus familiares emigrados que por los que obtienen aquí. Las dificultades de integración en su lugar de destino, hizo caer a un porcentaje minoritario de jóvenes en el problema estadounidense de las pandillas, llamadas "maras"; al ser deportados algunos de ellos, por sus actividades fuera de la ley, encontraron un caldo de cultivo en la desintegración de comunidades pobres, con alto grado de exclusión, y el fenómeno pandilleril creció exponencialmente ${ }^{45}$. La violencia delincuencial se volvió un fenómeno social grave, que además tiene consecuencias económicas que no son menores.

\section{Nuevas apuestas y avances en la privatización de las actividades estatales}

En el segundo gobierno de ARENA, el Presidente Armando Calderón Sol hizo una nueva apuesta: convertir al país en "una sola zona franca", que en poco tiempo - como expresó uno de sus impulsores - permitiría absorber a los seiscientos mil trabajadores del campo, en un país que suponían que había perdido su vocación agrícola. Esto implicaba una "simplificación impositiva" que dejaría al IVA el papel de casi única fuente fiscal, con la eliminación de muchos de los tributos existentes, así como centrarse en la competencia internacional de los bajos salarios. Se agregaba la sustitución de la moneda nacional, el colón, por el dólar de los Estados Unidos. Estos esfuerzos no llegaron a ser concretados, pues las reformas planteadas parecieron quedarse truncadas por la falta de respaldo de algunos sectores productivos del país ${ }^{46}$. Sin embargo, sus efectos negativos sobre el agro fueron notorios.

En ese mismo gobierno se tomó una decisión que sigue golpeando a las finanzas públicas: el esquema de privatización del sistema de pensiones. Expertos reconocidos internacionalmente hicieron una fuerte crítica al proyecto, indicando que la forma - no todos rechazaban la privatización como concepto estaba condenada a generar problemas fiscales casi insuperables; sin embargo, en la Asamblea Legislativa la reforma se aprobó tal cual la proponía el Órgano Ejecutivo, con los votos de su mayoría automática. Las consecuencias que ahora tiene muestra que las críticas de los expertos tenían sólido fundamento ${ }^{47}$. La carga

45. Este es un fenómeno muy complejo; su análisis no se agota en estas breves líneas.

46. De nuevo citamos a Vidal dado que su posición en ANEP le permitía acceso privilegiado a ciertas realidades: "Me consta que en ANEP no se procesaba este tipo de decisiones. (...) no había contemplado cambios drásticos en la política económica. A la membresía de la cúpula empresarial no sólo le preocupaba el impacto que eventualmente podían tener las medidas, sino también 'la forma inconsulta' con que aparentemente se iban a tomar las mismas". (Vidal, J. H. [2010] p. 391) 47. La Fundación Guillermo Manuel Ungo (FUNDAUNGO) tiene numerosas publicaciones sobre este tema. En la página web del ministerio de Hacienda pueden encontrarse análisis de la carga fiscal actual que representa la forma en que se pasó al sistema previsional de ahorro privado, y las disposiciones posteriores para paliar sus deficiencias, que trasladaron más responsabilidades al fisco. 
fiscal que esto representa es ahora de más del $2 \%$ del PIB, con tendencia a crecer. Con la intención de trasladar hacia adelante el problema, el cuarto gobierno de ARENA procedió al establecimiento de un fideicomiso; éste, de dudosa legalidad, se encarga de proporcionar los fondos necesarios para el pago de las pensiones del sistema de reparto que aún están pendientes, y los traslados y complementos al sistema privado, a través de certificados que obligatoriamente deben ser comprados por las Administradoras de Fondos de Pensiones con un porcentaje de los fondos ahorrados por los cotizantes del nuevo sistema.

El gobierno del Presidente Francisco Flores, hizo dos apuestas centrales: llevar a la práctica el sueño de dolarizar al país que no pudo realizar su antecesor, el Presidente Armando Calderón, y negociar un tratado de libre comercio con los Estados Unidos. La primera se volvió ley a finales del año 2000, y el 1 de enero del 2001 comenzó a implementarse; la ley convirtió en unidad de cuenta al dólar estadounidense, y prohibió la emisión de colones (se les dejaba valor legal para poder hacer transacciones, pero los bancos que los reciben están obligados a trasladarlos al BCR, el cual debe guardarlos; para disminuir las críticas, el gobierno presentó la medida como la creadora de una realidad bimonetarista, que en verdad es contraria al espíritu y al texto de la ley). Esto, según sus corifeos, convertiría a El Salvador en un centro financiero internacional competidor con el que desde hace años funciona en Panamá; sostenían que daría estabilidad económica y ventajas crediticias que, a la vez que favorecerían a los consumidores, atraerían la inversión nacional y extranjera. Los hechos han mostrado que algunas ventajas son innegables, pero a un costo muy alto para el país, y que lejos de haber convertido a El Salvador en un centro financiero, el sector bancario nacional no soportó la competencia internacional en su esfuerzo de regionalizarse; ahora está casi todo en manos de extranjeros, con sucursales que actúan localmente y que no pasan de ser agencias de muy bajo nivel de las grandes instituciones financieras internacionales. En ese quinquenio, el porcentaje del PIB que representó la inversión fue aún más bajo que en el anterior; el consumo fue el mayor dinamizador de la economía, equiparándose con el ingreso nacional, con la consecuencia de un muy débil ahorro nacional; siguió creciendo el monto de las importaciones y el déficit fiscal. Es muy relevante el hecho de que la medida arrebató al aparato del Estado una herramienta básica de política económica, que mucha falta hace para enfrentar de mejor manera la tendencia estructural de bajo crecimiento que por dos décadas ha presentado la economía salvadoreña. El año 2000 yo afirmaba que era una camisa de fuerza fácil de vender por las ventajas que eran aparentes de inmediato mientras las desventajas eran difícilmente percibidas por la generalidad de la ciudadanía por ser de mediano plazo, en tanto la vuelta a una moneda nacional es muy difícil política y económicamente por los efectos inmediatos que trae ${ }^{48}$ (Dada H., H. [2000]).

48. Poco antes de la conversión del dólar en la moneda del país, Ecuador había tomado una situación similar. Las condiciones económicas que explicaban la decisión del gobierno ecuatoriano no existían en El Salvador: desenfrenada inflación, pérdidas importantes y cotidianas en el valor de la moneda, inestabilidad política; por el contrario, nuestro país tenía baja inflación y un tipo de cambio estable, y la situación política y social era muy estable. Sin embargo, se puso ese ejemplo para reforzar los argumentos justificativos. Los dos terremotos que tuvo El Salvador en los dos primeros meses de 2001 hicieron pasar a segundo plano las discusiones sobre el tema. Por otra parte, algunos constitucionalistas 
El Tratado de Libre Comercio de Centroamérica y República Dominicana con los Estados Unidos de América (CAFTA-DR por sus siglas en inglés) fue presentado como el logro mayor de esta línea de pensamiento. No puede negarse que algunos beneficios ha producido el acuerdo comercial para algunos sectores productivos, pero muy lejos de las apuestas que se hicieron. El Ministerio de Economía ofrecía al país la creación de 400.000 empleos en los dos primeros años de su vigencia, debido a que seríamos un gran atractivo para las inversiones destinadas a satisfacer la demanda del país del norte. Si a eso uníamos los efectos de los tratados de libre comercio que se habían firmado con Chile y con México, la cifra crecía apreciablemente. Los hechos son tozudos, y de nuevo los resultados siguieron siendo muy lejanos de los esperados. Un dirigente empresarial llegó a expresar hace algunos años: "no perdimos, porque al menos salvaguardamos los empleos de la maquila que el trato que establecía la Iniciativa de la Cuenca del Caribe nos había permitido tener"; la afirmación es ciertamente demasiado negativa, pero expresa la distancia entre sus expectativas y lo que pudo obtener de beneficios. Más aún, la dispersión de aranceles, producidos por la forma bilateral en la que cada país negoció sus programas de desgravación con Estados Unidos, creó más dificultades a la posibilidad de crear una unión aduanera centroamericana, un viejo objetivo de la integración regional.

\section{Remesas familiares y la disminución de la pobreza}

Los logros que se atribuyen al "modelo" aplicado se basan fundamentalmente en la disminución de la pobreza. Se habla de cerca del $20 \%$ de la población que entre 1989 y 2004 dejó de ser pobre. No discutimos la cifra, que es muy probable que sea real; lo que como economistas nos llama la atención es que ese porcentaje es similar al que corresponde al volumen de migrantes que se estima que han salido hacia el norte, y que dada esta realidad y el monto de remesas que el país ha recibido (una política social privada de pobres a pobres) es sorprendente que se continúe con cifras de pobreza tan altas, salvo que el funcionamiento de la economía interna tuviera una tendencia a producir pobres que fuera superada por los efectos de la migración y las remesas. Lo que sí es constatable es que el objetivo de concentrar riqueza se logró, incrementando la desigualdad, aunque no se transformó en un coeficiente de inversión más elevado como decía el supuesto neoliberal.

\section{Una nueva transformación en la estructura de propiedad}

Mientras todo lo mencionado acaecía, un progresivo cambio de propiedad comenzó a darse en distintas áreas estratégicas de la economía. Industrias emblemáticas del país fueron adquiridas por empresas transnacionales, siguiendo la tónica del mundo globalizado; la producción de cerveza y la industria cementera, para poner dos ejemplos de ellas, pasaron a manos extranjeras, lo que ponía límites a 
su capacidad de llevar sus productos a mercados externos. Las administradoras de fondos de pensiones, que en un inicio eran en parte propiedad de nacionales, en repetidos casos ligadas a los bancos privatizados, se trasladaron progresivamente a manos extranjeras y a disminuir en su número hasta quedar solamente dos. Los bancos, como dijimos arriba, pasaron también a ser vendidos a bancos extranjeros, proceso que se dio vertiginosamente a partir del año 2005. El sector que se había concebido como eje de reconstitución de la elite económica nacional dejaba de estar en sus manos después de un período de expansión en la región que los había llevado a otras dimensiones. Si bien lograron pingües ganancias en las negociaciones de venta, no es menos cierto que la naturaleza de su actividad económica central se alteró, y por lo tanto se afectaron sus bases de poder: sus principales actividades están centradas en el sector de los no transables. Éste es un fenómeno que ha sido poco analizado en el país, y que requiere un profundo estudio. Menos tenemos análisis académicos que nos planteen las consecuencias sociales de cambios tan bruscos y tan frecuentes en la estructura de propiedad, sobre la estructura social del país y sobre las condiciones en la que se puede aplicar una política de desarrollo.

\section{La existencia de problemas estructurales no resueltos}

El modelo encontraba dificultades para producir resultados satisfactorios. El problema no era nuevo. Desde 1996, cuando era obvio que se había entrado en un momento de desaceleración, hubo analistas que llegaron a la conclusión de que ésta no era tanto una consecuencia de fenómenos coyunturales sino más bien fruto de "la existencia de problemas estructurales no resueltos"49 (que lamentablemente en veinte años no se han abordado adecuadamente, y que para no pocos ni siquiera existen); también los organismos internacionales reaccionaron pidiendo cambios en las políticas, poniendo atención además en problemas como la tendencia negativa del balance de las finanzas públicas, la urgencia de contar un marco jurídico confiable, la necesidad de un serio combate a la corrupción.

Una constatación de los problemas que tenía el modelo aparece en el documento de FUSADES titulado Estrategia económica y social 2004-2009, que contenía las propuestas de la institución del sector privado para el gobierno que se iniciaría en junio de 2004. En primer lugar, menciona las dificultades que los empresarios salvadoreños habían tenido para encontrar los nichos de exportación que les permitieran aprovechar las aperturas del comercio internacional ${ }^{50}$. En segundo lugar, partía del reconocimiento del manejo responsable que tradicionalmente

49. Ver Vidal, J. H. [2010] p. 385.

50. Para la elaboración de esta Estrategia, FUSADES contó con un equipo de expertos de la Universidad de Harvard. Las palabras exactas son las siguientes: "Más grave aún es que el país sufre de una escasez de ideas productivas que puedan crear oportunidades alternativas de crecimiento. (...) Un indicador es el hecho de que la canasta de exportación a Estados Unidos es maquila en un 88\%". Señala que este sector cuenta con estímulos fiscales en El Salvador y no tiene aranceles en el ingreso de los productos a ese país. (FUSADES [2003], p. 8 y 9) 
ha hecho El Salvador de sus políticas monetarias y fiscales, para pasar a decir que "en los últimos cuatro años, a medida que la economía se ha desacelerado, los déficits fiscales han aumentado y algunas campanas de alarma han comenzado a sonar con relación al ritmo del endeudamiento público". Pasa posteriormente a afirmar "que la estabilidad fiscal no está garantizada por las políticas actuales ${ }^{51 ",}$ revelando que "el país tiene ya un déficit fiscal significativo" y que de "continuar la tendencia, el país perderá su grado de inversión”. Al señalar los factores que son causa inmediata de esa situación, señala sin ambages que "el costo fiscal de la transición del régimen de seguridad social es significativo" y que "el costo fiscal de las pensiones oscilaría entre 2 por ciento y 2,7 por ciento". Previene, además, que "si bien la disciplina fiscal es recomendable bajo cualquier esquema cambiario, lo es todavía más en una economía dolarizada" (FUSADES, [2003] p. 29).

\section{De la alternancia a la crisis fiscal}

El cuarto gobierno de ARENA: políticas sectoriales y subsidios

En 2004 ARENA ganó la elección presidencial por cuarta vez consecutiva; obtuvo una apreciable mayoría de votos pese a que su partido había dado señales de debilidad en los anteriores comicios legislativos. Su rival principal fue Shafick Handal, líder del Partido Comunista por muchos años y entonces principal dirigente del FMLN. El candidato presidencial de ARENA, Antonio Saca, era un empresario radial que venía de ser presidente de ANEP; su campaña estuvo centrada en dos ejes: un triunfo del FMLN significaría problemas para los emigrados a Estados Unidos, poniendo en peligro las remesas familiares ${ }^{52}$; mostrarse como representante de "la derecha social", con sensibilidad a la situación de los ciudadanos menos favorecidos, ofreciendo establecer una política de subsidios, resolver el problema de la seguridad pública, y combatir la corrupción.

El gobierno de Saca estuvo lejos de plantear una apuesta estratégica como las que asumieron sus predecesores. Puede afirmarse que tenía consciencia de la situación que heredaba, y que debía enfrentar algunos retos centrales para corregir el desempeño bastante pobre que la economía había tenido durante una década, para contrarrestar la creciente violencia criminal, para atraer a la porción del electorado que - mostrándose inconforme con los pocos beneficios que recibía de la dinámica económico-social del país - podía poner en riesgo la continuidad de la derecha en el manejo del aparato del Estado. Por supuesto, un requisito para todo ello era resolver el problema ya presente en las finanzas públicas. 
En el gobierno de Cristiani se afirmó que “la mejor política económica sectorial es la que no se tiene ${ }^{53}$ ", considerando que la misma existencia de ese tipo de políticas violentaba la dominación de las señales del mercado que darían el rumbo a la economía. En la medida en que algunos sectores económicos comenzaron a percibir limitaciones a sus perspectivas, dada la imposibilidad de establecer una verdadera base exportadora diversificada que había mostrado el modelo básico implementado ${ }^{54}$. El gobierno de Saca decidió emprender algunas políticas sectoriales: se entregó el ministerio de Agricultura y Ganadería a un ejecutivo de una gremial del sector agroexportador, con la misión de revertir la visión de que el campo ya no era un espacio productivo importante ${ }^{55}$; la nueva ministra de Economía inició conversaciones con la Asociación Salvadoreña de Industriales para diseñar una política para el sector; se creó el ministerio de Turismo, se aprobó una ley para dar estímulos fiscales al sector, y se inició un fuerte activismo estatal para promover el turismo interno y externo. Sin embargo, las políticas no tuvieron los necesarios alcances transformadores, pues carecieron del marco de una concepción de renovación del modelo que les diera coherencia.

En lo social se procedió a establecer el programa llamado Red Solidaria que distribuía transferencias a sectores en situación alta de pobreza, condicionadas a la utilización de los servicios de salud y educación del Estado; también se emprendió una política de vivienda que, además de posibilitar la obtención de un lugar adonde habitar a personas de ingresos bajos, pretendía estimular la industria de la construcción. En la segunda mitad del gobierno, a estas medidas se agregó un fuerte subsidio para las familias que tienen bajo consumo de electricidad, así como medidas fiscales para favorecer a los contribuyentes de menores ingresos y aumento de prestaciones a los empleados formales afiliados al Instituto Salvadoreño del Seguro Social ${ }^{56}$.

Poco después de asumir el gobierno, el ministro de Hacienda inició conversaciones con los diputados de la oposición ${ }^{57}$ con el objeto de encontrar compromisos para solventar las tendencias estructurales al desequilibrio que presentaban las finanzas públicas. Para respaldar su posición utilizaba la Estrategia Económica y Social 2004-2009 (FUSADES [2003], citada en el acápite 3.7), así como los documentos que habían servido de base para su elaboración. Intentaba lograr compromisos

53. Miembros del gabinete de Alfedo Cristiani repetían frecuentemente esta frase, que estaba al centro de la visión radical de dejar toda decisión económica al mercado, aunque como ya hemos señalado no se abandonara el uso patrimonial del Estado para favorecer los intereses de los empresarios-funcionarios y sus allegados.

54. Al cual, como se ha expresado se le fueron agregando nuevos objetivos que tampoco fueron alcanzados.

55. La afirmación más tajante en este sentido se hizo durante el gobierno de Francisco Flores, cuando se afirmó que era más conveniente importar los alimentos que producirlos, confiando, como antes se ha dicho, en que los trabajadores agrícolas podían ser absorbidos por el "boom" industrial que anhelaban.

56. No es el espacio para una descripción de las medidas tomadas.

57. Quien esto escribe era en ese momento diputado a la Asamblea Legislativa, y participó en el diálogo. 
que le dieran viabilidad política a reformas a las leyes fiscales, a partir de la definición en conjunto de cuáles tenían posibilidad de mejorar la situación. En el diálogo se pusieron sobre la mesa, entre otras medidas a ser discutidas: el incremento de la tasa marginal impositiva a las rentas personales más altas; la aprobación de un impuesto predial, que con características diferentes restituyera el impuesto a la propiedad eliminado una década atrás (véase acápite 2.1); el combate a la evasión y a la apropiación indebida del IVA, así como cerrar los espacios de elusión; la necesidad de tomar medidas para hacer frente a la carga fiscal del sistema previsional reformado.

Si bien las negociaciones parecían avanzar, rápidamente surgieron las críticas, primordialmente desde el seno del sector empresarial. El argumento fue el efecto que cualquier imposición tendría sobre el crecimiento, y que más bien el gobierno debía ajustarse a no gastar más de lo que ya le ingresaba. El ministro fue destituido poco tiempo después, esfumándose así la oportunidad de realizar una reforma integral de la situación fiscal. Su sucesor dio marcha atrás, dedicándose el gobierno a tomar medidas menores, para resolver problemas de caja, y en varios casos de manera incoherente. Y cuando esta vía no proporcionó las fondos para que el presupuesto corriente cubriera determinados egresos, y ante la reacción negativa del FMLN ante la solicitud de aprobación de nuevos créditos internacionales, se procedió a encontrar formas ingeniosas para tirar para adelante los problemas sin resolverlos, aun cuando éstas fueran de muy dudosa legalidad $\mathrm{y}$, por supuesto, incapaces de ser parte de una respuesta que respondiera al carácter estructural de la tendencia deficitaria: el Fideicomiso para Inversión en Educación, Paz Social y Seguridad Ciudadana y el Fideicomiso de Obligaciones Previsionales ${ }^{58}$. Los intereses de la elite económica, poco dispuesta a hacerse cargo de su obligación de contribuir al Estado de acuerdo a los beneficios que recibe, impidieron una visión de mediano plazo en la construcción de la respuesta a las dificultades.

\footnotetext{
58. Ambos fideicomisos contaban con su propia estructura, y sus leyes comisionaban al Banco Multisectorial de Inversiones (BMI, ahora BANDESAL) para administrarlos. Inicialmente contaban con un capital muy limitado, y su objetivo era más bien soslayar de manera poco legal - o totalmente ilegal, si se quiere - el requerimiento constitucional de una votación de al menos dos tercios de los diputados electos para poder contratar deuda pública; los decretos de creación les daban a los fideicomisos la capacidad de emitir certificados de deuda para cumplir sus obligaciones respectivas: en el primero, financiar primordialmente actividades de seguridad pública; en el segundo, hacerse cargo de las responsabilidades fiscales excesivas que creó la reforma al sistema de pensiones. En este caso, las Administradoras de Fondos de Pensiones tienen la obligación de comprar los certificados de obligaciones previsionales que el fideicomiso emita hasta un $45 \%$ de los fondos de las cuentas de ahorro de los cotizantes. Las leyes no tienen una disposición expresa que obligue al Estado a hacerse responsable de proporcionar los fondos para cancelar la deuda al vencimiento de los certificados ni para pagar intereses, pero en la práctica lo ha hecho.
} 


\section{El camino a la alternancia}

En el campo de la competencia político-electoral, los resultados de los comicios siguieron siendo respetados, y aceptados por los partidos políticos participantes. El FMLN se recuperó de la amplia derrota en la elección presidencial de 2004, manteniendo su presencia en la Asamblea Legislativa y en los gobiernos locales, mientras para ARENA la expectativa de obtener en esos comicios un triunfo similar al de los presidenciales no se concretó; la votación obtenida no se tradujo en un número de diputados que les diera una cómoda mayoría legislativa. La que pudo ser una prueba difícil fue la elección municipal del año 2006, cuando el FMLN ganó en la ciudad de San Salvador por una diferencia de una cuarentena de votos sobre ARENA; las presiones de grupos de derecha radical para desconocer el resultado fueron respondidos la misma noche de la elección con una masiva manifestación del partido ganador. La decisión de respetar el resultado calmó las posibilidades de incidentes mayores. Sin embargo, esto no era signo de que las relaciones entre el gobierno de Saca, y su partido ARENA (del que era presidente), con el FMLN fueran cordiales; después de un período inicial de diálogo, las tensiones se mostraron con claridad. Como se dijo antes, el FMLN tomó una actitud negativa ante las peticiones de aprobación de empréstitos - en casos justificadamente, en otros no - sin que se diera un diálogo constructivo para encontrar solución a los entrampamientos; esto se vio agravado cuando se crearon los fideicomisos mencionados, con una mayoría obtenida a través de la adhesión de los pequeños partidos de derecha ${ }^{59}$.

La economía inició una breve etapa de mayor crecimiento. Luego de un bajo incremento del PIB en 1,9\% en 2004 fue ascendiendo hasta llegar a lograr 3,9\% en 2006, y 3,8\% en 2007. Sectores como la agricultura y el turismo tuvieron tasas altas de crecimiento, estimuladas en parte por las medidas mencionadas arriba, así como el sector comercio. Para la CEPAL, los factores básicos para hacer crecer la economía a ritmos superiores a su crecimiento potencial fueron el aumento de la inversión pública y privada, el ritmo de incremento del monto de remesas familiares (12\% anual) y el turismo (citado por ICEFI, [2015]) $)^{60}$. Pero en 2008 ese breve período de expansión terminó, y la actividad económica sólo se incrementó en 1,3\%; en 2009 a los factores internos se agregó el efecto de la Gran Recesión de la economía internacional, y el PIB tuvo un decremento de 3,1\% en 2009.

59. El grupo parlamentario del partido Cambio Democrático, al que yo pertenecía, rechazó categóricamente la constitucionalidad de los fideicomisos y también tuvo una actitud crítica frente a diversos proyectos de crédito estatal poco explicados, y sin mecanismos de control adecuados. En otros casos consideramos una oposición más cerrada que lo adecuado de parte de los colegas del FMLN. No era fácil tener un diálogo constructivo con una fracción que sabía que podía aprobar decretos inconstitucionales con posibilidades prácticamente nulas de que la sala de lo Constitucional tomara decisiones que contrariaran las intenciones del Órgano Ejecutivo.

60. Hay que relevar que la industria de la maquila, pese a un período de expansión de la economía de los Estados Unidos, tuvo tasas negativas de crecimiento, y que buena parte de la inversión extranjera que ingresó al país estuvo dirigida a la compra de empresas existentes. 
Para Vidal la reducción del crecimiento sólo en forma parcial puede ser atribuida a la crisis internacional, además de haberse iniciado antes de que esta pudiera afectar a la economía salvadoreña, dado el desfase con el que los comportamientos de la economía del país del norte se registran en los de nuestras variables económicas. Al opinar sobre la reducción de la tasa de crecimiento del 2008 él expresa: "En la práctica lo que esto significa es que el comportamiento de la economía seguía siendo presa de los bajos niveles de ahorro y de inversión, mientras las presiones sobre el sistema se volcaban hacia el exterior a través de un marcado crecimiento de las importaciones de bienes y servicios. De hecho éstas representaron en 2008 el 49,8\% de la oferta global, superando en más de 20 puntos porcentuales, el coeficiente de exportaciones" (Vidal [2010], p. 452).

Entretanto la campaña electoral para las elecciones de 2009 estaba en pleno desarrollo. En éstas, 15 años después de las “elecciones del siglo" de 1994, eran todos los cargos de elección popular los que estaban en juego. Saca desarrollaba todos los esfuerzos para darle continuidad no sólo al control de ARENA sobre el órgano ejecutivo, sino de su propio grupo como conductor del país. El FMLN, analizando su fracaso de 2004, se decidió por un candidato externo, un periodista que se había hecho popular a través de un programa de entrevistas en el que ponía en cuestión a los dirigentes políticos; su lanzamiento de hizo a través de un movimiento ciudadano, de variada composición, que otorgaba credibilidad a la independencia del candidato. Las encuestas daban un resultado a favor del FMLN, sin distancias holgadas. Los otros partidos políticos tenían poco que hacer en esa disputa, y pese a que algunos tenían sus propios candidatos presidenciales, su esfuerzo estaba más en las competencias legislativas y municipales.

La situación de las finanzas públicas se convirtió en un factor importante que era capaz de afectar la elección, o las posibilidades de gobernar si se ganaba la presidencia. La dinámica deficitaria daba señales de alivio en los primeros años del gobierno de Saca, pero pronto los problemas estructurales comenzaron a mostrarse con claridad, agravados por la política de subsidios que se decidió emprender para mitigar la situación de los más vulnerables, y según algunos para ganar su voluntad política. Alguna colaboración comenzó a darse entre los dos mayores partidos para enfrentar un problema que se había vuelto común, dado que ambos tenían perspectivas reales de ser partido de gobierno en el siguiente período. Sin embargo, las acciones que se tomaron estuvieron muy alejadas de la necesaria visión estructural requerida, y se redujeron a enfrentar problemas de caja, lo que era indispensable pero totalmente insuficiente.

Los comicios electorales correspondientes al año 2009 incluían la elección de todos los cargos definidos por votación directa de los ciudadanos. El mes de enero fue señalado para seleccionar a los diputados y a los miembros de los concejos municipales, y dos meses después, el 15 de marzo, fue la fecha escogida para definir la presidencia y vicepresidencia de la República. En los primeros, el FMLN 
superó en votación a ARENA, obteniendo 35 de los 84 cargos parlamentarios, en tanto el partido de la derecha lograba 32. Es decir, las mayorías calificadas (dos tercios de los diputados electos) no podían conseguirse sin la participación de los dos grandes institutos políticos. Para la elección de marzo, dos partidos de derecha retiraron a sus candidatos presidenciales con el fin de concentrar esfuerzos para que ARENA ganara las elecciones; los dos partidos social-demócratas, que no tenían aspirante a la presidencia, decidieron apoyar a Mauricio Funes, candidato del FMLN, sin formalizar ninguna alianza con el partido que los postulaba. Sólo quedaban dos candidatos. El resultado fue un gane muy estrecho de la izquierda política, pues Funes obtuvo 51,3\%, menos de 70.000 por encima de Rodrigo Ávila $(48,7 \%)$, en un total de un poco más 2’600.000 votos válidos.

La tensión no se hizo esperar. La misma noche de la elección comenzó a haber expresiones negativas de una derecha acostumbrada a la utilización patrimonial del aparato del Estado. El discurso de aceptación del triunfo de Funes fue un llamado a la tranquilidad y a trabajar unidos para sacar adelante el país, a actuar en el diálogo en busca de los intereses comunes de la nación. El presidente Saca, por su parte, colaboró aceptando los resultados muy poco después de anunciados, reconociendo la derrota de su candidato y ofreciendo colaborar en la transición.

El proceso de conversaciones entre el gobierno entrante y el saliente descubrió que la dimensión del problema fiscal era aún más grave de lo que se había previsto. Las previsiones para 2009 eran claramente negativas, y el efecto de la Gran Recesión sobre la economía salvadoreña determinaba en alguna medida ese comportamiento. Vidal - en su libro publicado en 2010, un año después - afirma: “Todavía en ese momento, no había salido a luz pública el gran agujero fiscal que dejaría la administración Saca, problema que llevó a fuertes negociaciones entre los dos partidos mayoritarios para superar una situación inédita en el manejo de las finanzas públicas, donde el gobierno saliente dejaba atrasos en el pago de proveedores, incumplimiento en la devolución de la renta, rezagos en las transferencias a las municipalidades a través del FODES y hasta riesgos de no tener con qué pagar los sueldos de sus propios empleados (La Prensa Gráfica, 23 de mayo de 2009)” (Vidal [2010] p. 456). Más adelante agrega: “(...) como se dijo, el curso negativo de la economía no puede ser revertido mientras el manejo de las finanzas públicas, que ha sido considerado el talón de Aquiles desde la segunda administración de ARENA, deje como secuela para el 2009, un déficit que ronda el $5 \%$ del PIB, desajuste que no se registraba desde la década de los ochenta". (Vidal [2010] p. 458. Ambos resaltados son míos.) ${ }^{61}$.

61. Yo participé en la transición entre los dos gobiernos en mi carácter de Secretario General del partido Cambio Democrático; al final del proceso, una semana antes de su toma de posesión, el presidente Funes ofreció al partido que yo presidiera la cartera de Economía, lo que se aceptó. Fui testigo y actor de estos hechos; sin embargo, he preferido el testimonio de una persona cuyas visiones no coinciden con las de la izquierda y expresa con honestidad sus puntos de vista. En definitiva, el déficit del año 2009 fue calculado en 5,7\% por el Banco Central de Reserva, un nivel de mucho riesgo para una economía dolarizada. 
Un gobierno de composición diversa, que incluía militantes reconocidos del FMLN, miembros del grupo Amigos de Mauricio, y algunos dirigentes de Cambio Democrático, asumió la conducción del país. Su reto era enorme: cumplir con las promesas de cambio hechas en las elecciones, lo que significaba eliminar los elementos de aprovechamiento patrimonial de la administración pública y combatir la corrupción, a la vez que realizar los cambios requeridos en un modelo que había ya mostrado su fracaso; eso en una situación económica en la que se preveía que ese año el PIB iba a caer entre 3 y 4\%, y que se tendría el mayor déficit fiscal en mucho tiempo. Las autoridades del gobierno saliente, debe reconocerse, ayudaron a tomar las medidas para trasladar en el tiempo compromisos que era imposible cumplir de otra manera; quedaba al gobierno entrante la tarea de impulsar las medidas que requerían visión de más largo plazo.

\section{La práctica de la alternancia}

En nuestro país, desde nuestra independencia, hemos asumido las formas de la democracia liberal; las diversas constituciones de nuestra historia han establecido siempre la existencia de tres poderes independientes, aunque responsabilizados de actuar coordinadamente en busca de los intereses superiores de la sociedad. Sin embargo, la fidelidad a esas normas ha estado ausente en casi toda nuestra vida como nación. A mediados de los años 90 del siglo pasado, en una ponencia presentada a petición de la Corte Suprema de Justicia (que se titulaba "El derecho visto por alguien que no es abogado"), expresaba que hasta entonces mi vida había transcurrido siendo testigo de la falta de independencia de los poderes u órganos del Estado, y que más bien - al menos hasta los acuerdos de paz - una norma de facto, muchas veces alejada de la Constitución Política, había sido aplicada en desmedro de la vivencia democrática establecida en nuestra carta magna. En última instancia, la ley primaria sólo encontraba vigencia práctica en tanto cuanto no contrariaba esa norma fáctica, bajo la decisión discrecional de la institución verdaderamente responsable de administrar el aparato del Estado: las Fuerzas Armadas.

Con los Acuerdos de Paz firmados ese 16 de enero de 1992, y las previas reformas constitucionales del año anterior, se pretendía establecer las bases para la construcción de una real institucionalidad democrática. La protección de la pluralidad política y la independencia de poderes del Estado, se decía, estarán garantizados por la inclusión de los alzados en armas en el sistema de partidos, por los reforzados requisitos para las elecciones secundarias, por las normas de supeditación de la Fuerza Armada al gobierno civil, etcétera. Si bien ganada por un partido cuyo origen está en los grupos que practicaban la regla fáctica del pasado, ARENA, la elección de 1994 pareció significar un paso en el sentido correcto, y por tres años parecía haber un relativo respeto por la independencia de poderes (sin que eso pueda interpretarse como afirmando que antes, durante y después de los Acuerdos de Paz no se tomaran decisiones que 
contradecían lo que se firmó). Pero las realidades sociales, y la intensificación del patrimonialismo del Estado como factor estructural del funcionamiento de grupos económicos y sociales, pronto comenzaron a conspirar contra lo que se había logrado. Con mucha frecuencia, desde la Presidencia de la República se manipulaban decisiones de los tres órganos del Estado, y de las entidades del Ministerio Público, utilizando los elementos mismos de la legalidad recién creada.

Como ya hemos expresado, si bien se pretendía estar en un Estado democrático, sin restricciones para los partidos políticos o las ideologías, constantemente se utilizaban todos los medios al alcance de las instancias políticas y de los poderes fácticos para descalificar a las izquierdas como potenciales partidos de gobierno. Pese a ello, en la elección del año 2009, la ciudadanía eligió cambiar de partido conductor del Órgano Ejecutivo ${ }^{62}$. La alternancia, un hecho no conocido desde los Acuerdos de Paz, transformaba las reglas de juego, en el sentido que el espíritu de éstos señalaba. ARENA, y los sectores sociales que son sus patrocinadores, perdían el control y la manipulación de los tres órganos del Estado, que mantenían con la cooperación negociada de otros partidos. Para aquellos que asumen la creencia en la democracia se generaba una oportunidad histórica que no debía desaprovecharse. Y para el FMLN significaba la prueba mayor de su incorporación a un Estado con sistema político de democracia liberal, aunque - por las alianzas que le permitieron ganar las elecciones - fuera el partido de gobierno sin controlar directa y totalmente al Órgano Ejecutivo.

Desde el inicio de su período, el gobierno de Funes mostró apertura ${ }^{63}$ al diálogo y profundo respeto a las normas constitucionales. Quizá la primera prueba importante para esta actitud era la elección de cinco magistrados propietarios de la Corte Suprema de Justicia y sus respectivos suplentes, la cual debía realizarse unas semanas después de la toma de posesión del nuevo gobierno.

62. El único cambio de gobierno que hasta entonces podía calificarse como "alternancia entre partidos con visiones contrapuestas" fue en 1931, cuando el Partido Agrario Laborista - fundado y presidido por un miembro de la elite del país, convertido en social demócrata en Gran Bretaña, y apoyado por sectores intelectuales progresistas y por asociaciones de trabajadores y artesanos - asumió la presidencia en medio de una grave crisis social y económica provocada por la Gran Depresión que vivía el mundo. A los nueve meses fue derrocado por su vicepresidente, un general del Ejército, instaurando la serie de gobiernos militares que el país tuvo por medio siglo.

63. El gobierno de Mauricio Funes tuvo dos etapas muy marcadas. En los dos primeros años no sólo se mostró dispuesto al diálogo, sino - como se ejemplificará más adelante - ayudó a resolver entrampamientos en otras instancias del aparato del Estado. En la segunda mitad de su administración fue tomando una creciente actitud de confrontación, en no poca medida provocado y/ ayudado (no señalo causa o efecto) por una nueva dirección de la empresa privada que cambió la actitud de negociación fuerte pero respetuosa de su antecesora, por un discurso público cargado de ofensas. 
El proceso estaba estancado en la Asamblea Legislativa, pues se requería la participación de los votos de ARENA y el FMLN para obtener la mayoría calificada que la Constitución Política exige. La dificultad mayor surgía del hecho de que cuatro de esos magistrados a elegir debían pasar a ser miembros de la Sala de lo Constitucional ${ }^{64}$, posición que ante la realidad de la alternancia adquiría una relevancia superior a la del pasado. Después de un estancamiento en el proceso, la intervención mediadora de la Presidencia de la República fue un factor de racionalización de la negociación entre los grupos partidarios encargados de realizar la elección de segundo grado. El acuerdo logrado pareció satisfacer en ese momento, con la principal consecuencia en la composición de la Sala de lo Constitucional: con cuatro abogados de diferentes visiones, con prestigio de capacidad profesional y honestidad personal, que se esperaba iban a manejar sus cargos con independencia y buen juicio serían electos. Aunque, como más adelante veremos, las dificultades generadas por las visiones poco democráticas o por los hábitos del pasado - o ambas situaciones a la vez - volvieron difícil la vivencia de mayor autonomía entre los órganos del Estado; el comportamiento de los distintos actores político-institucionales, incluidos los funcionarios de la Corte Suprema de Justicia, tuvieron en un momento $u$ otro actitudes que causaron conflictos, pese a que al final las sentencias se cumplieron.

Es evidente que la transparencia no es coherente con la acción práctica de un gobierno de corte patrimonialista. Pese a presiones de sectores ciudadanos - y, en ciertos momentos, aun de las embajadas de los Estados Unidos y de otros países cooperantes - un proyecto de ley que buscaba garantizar el derecho del ciudadano a obtener información de las instancias del Estado permanecía en estudio, sin lograr la aprobación de la Asamblea Legislativa. El gobierno creó una Subsecretaría de Transparencia con el encargo de hacer cumplir a los funcionarios la responsabilidad de informar de sus actuaciones, y también respaldar la aprobación del decreto legislativo; dado que ahora sí, desde la oposición, la derecha tenía interés en la transparencia, se obtuvieron sus votos. Pese a deficiencias a veces notorias en el cumplimiento de sus disposiciones, el instrumento legal ha significado un vuelco sustancial en la posibilidad de acceso al conocimiento del quehacer del Estado; dicho esto sin ignorar las potencialidades que tienen las innovaciones cibernéticas para facilitar la obtención de esos objetivos.

No cabe la menor duda de que, en el ámbito político-institucional, la alternancia es el hecho más relevante desde los acuerdos de paz. No es sólo que por primera vez quienes habían estado alzados en armas llegaban a tener cargos en el órgano Ejecutivo, lo que en sí mismo mostraba un avance en la apertura de los

64. La Sala de lo Constitucional es una de las cuatro salas de la Corte Suprema de Justicia; ésta tiene quince miembros electos por tercios cada tres años. Las decisiones de la Sala de lo Constitucional requieren al menos cuatro votos. El magistrado que permanecía en ella era visto como cercano por la derecha empresarial y política, y por ello la elección se volvía decisiva para la posibilidad de una acción autónoma de tan decisiva instancia. Por varias semanas el acuerdo entre los partidos no llegó a concretarse y la mencionada Sala había quedado acéfala, y la Corte no tenía presidente. 
espacios políticos (pese a las resistencias que se han mencionado). Se trató de un cambio radical para el manejo de los intereses de los distintos grupos sociales, en especial para las elites dominantes que no concebían perder las elecciones, y menos quedarse sin el control del aparato del Estado; para ellas significó orientar el manejo de su poder económico, social y mediático a fin de generar las mejores condiciones de negociación que les fuera posible, ante un gobierno que consideraban contrario a sus intereses. Pero también generó exigencias de cambios para los movimientos sociales ligados a la izquierda, acostumbrados a hacer demandas a gobiernos a los cuales habían estado abiertamente confrontados.

Los cambios no son fáciles, y menos cuando, lejos de nacer de convicciones de los actores, surgen de imposiciones de las realidades del desarrollo de un proceso que se ha aceptado como única forma de evitar costos mayores. La más grave muestra de lo dicho se dio el año 2011. La Sala de lo Constitucional había venido aprobando diversas sentencias que dejaban sin efecto decisiones legislativas tomadas durante gobiernos anteriores, algunas de las cuales facilitaban el funcionamiento financiero de Casa Presidencial, otras declaraban inconstitucionales elecciones de segundo grado, etc. Sea cual sea la opinión que se tenga de las sentencias - y quien esto escribe cuestiona varias de ellas - existe la obligación de cumplirlas sin mecanismo de apelación ${ }^{65}$. El clímax del conflicto llegó cuando parecía inminente que dicha Sala sentenciaría sobre una demanda de declaración de inconstitucionalidad de la ley de amnistía sobre los delitos cometidos en la larga guerra civil; dirigentes de ARENA, potencialmente indiciados en el proceso judicial sobre el asesinato de los padres jesuitas en 1989 que se llevaba a cabo en España, buscaron una manera de obstaculizar - si no impedir - las decisiones de ese tribunal, que requería cuatro votos de sus cinco componentes para tomar decisiones. Teniendo la convicción de que el magistrado electo antes de 2009 era persona que podía defender sus intereses, decidieron impulsar un proyecto de ley exigiendo unanimidad de la Sala de lo Constitucional para sus resoluciones. En la búsqueda de una vía para lograr su aprobación, procedieron a negociar con el Presidente Funes, que se sentía afectado por otras decisiones de la Sala, y llegaron a un acuerdo. Con los votos de los partidos de derecha (ni el FMLN ni Cambio Democrático apoyaron el proyecto) la Asamblea Legislativa lo convirtió en decreto, que de inmediato recibió la sentencia del presidente para su publicación. La Sala de lo Constitucional sentenció la inaplicabilidad de la resolución de la Asamblea Legislativa, y los tres órganos del Estado se vieron inmersos en un largo conflicto; en éste, curiosamente, el FMLN fue la parte más vociferante contra los magistrados que componen la instancia judicial. A partir de allí, la discusión

\footnotetext{
65. No podemos entrar en detalles, pues sería prolongar demasiado este texto. Nos hemos detenido un poco en este caso porque ejemplifica la naturaleza de los conflictos. Valga decir que lo que intentamos expresar es que hay mucha dificultad de acomodarse a la autonomía de los órganos del Estado, y que algunos preferirían el viejo control desde el Ejecutivo, y para otros la tentación es la supeditación de los otros órganos a decisiones de la Sala de lo Constitucional. Aprender a caminar en democracia requiere convicciones democráticas, además de exigir práctica para acomodarla a la vida cotidiana. Este es el momento que se vive en el país.
} 
entre titulares de los diferentes órganos del Estado ha sido casi constante, y en no pocas ocasiones en términos más ofensivos que deliberativos, siguiendo la tónica de descalificación del otro que lamentablemente suele tener la contraposición de ideas y de hechos en las que participan dirigentes sociales y partidarios. Pese a todo, al final de cuentas todos se han sometido a las sentencias del tribunal constitucional, aun en los casos en los que se considera que han excedido sus facultades constitucionales.

Un cambio de actitud de otra instancia del Estado que vale la pena resaltar es la de la Fiscalía General de la República. Existía la convicción de que era necesario hacerla pasar de una entidad controlada a partir de los criterios del grupo de poder, a una que cumpliera su función como institución pública al servicio de la justicia; se eligió un nuevo fiscal con esa expectativa, aunque después de tres años de gestión hubo más declaraciones que realidades, y tristemente ha terminado en la cárcel acusado de haber utilizado su cargo para enriquecerse a través de favores a empresarios y a políticos. Un nuevo fiscal elegido en 2016 ha comenzado dando algunas muestras de caminar en el sendero adecuado, pero la experiencia exige que se tenga una opinión con reservas. Su actuación ha permitido convertir al año 2016, como dicen los medios de prensa, en el año del “destape de la corrupción”, en lo que la Sección de Probidad de la Corte Suprema de Justicia tiene importante participación.

En síntesis, el país ha transitado en un camino de institucionalización democrática más intenso, fruto en cierta medida de la dinámica que se abrió al cambiar las armas por la competencia electoral para definir la conducción del país; como se ha dicho, era una institucionalidad que no terminaba - y no termina - de librarse de las viejas realidades de decisiones con control desde la presidencia, estuviera ésta en manos militares o en manos civiles. La alternancia abrió una amplia vía para nuevos pasos en la consolidación de la democracia, con las características dialécticas que son intrínsecas a un proceso como éste. Y con una oposición que no terminó de aceptar el derecho de la izquierda de gobernar al país, y menos de ser oposición en una estructura democrática; y un partido de gobierno que no ha logrado transformarse adecuadamente para asumir su papel en el desarrollo económico, social y político del país que ahora debe conducir. Y la llamada sociedad civil, en muchos casos insiste en utilizar los espacios adquiridos más para hacer "anti-política" que para hacer avanzar la institucionalidad democrática.

\section{La alternancia y la política económica}

En los capítulos anteriores se mencionó cómo no se lograron las apuestas estratégicas fundamentales del modelo aplicado desde 1989. El equipo que acompañaría a Funes en su gobierno tenía la convicción de que habría que hacer cambios fundamentales en las políticas económicas, acrecentando la presencia del Estado en la dinamización de la economía sin alterar el sistema de libre 
empresa imperante. Si ya el gobierno del Presidente Saca careció de una visión estratégica para reactivar la economía, y se había reducido a cambios de cierta importancia pero absolutamente insuficientes, ahora era necesario impulsar un proyecto más integral que se centrara en la producción y permitiera una más dinámica generación de empleo.

Sin embargo, al terminar el período, no era posible concluir que la tarea se había hecho. No quiere decir que no se hicieron esfuerzos en áreas específicas, en las que cambios de importancia han tenido resultados positivos. La misma naturaleza del gobierno, una alianza de sectores con visiones muchas veces encontradas, dificultaba la tarea. La expectativa de la población sobre rápidas respuestas a sus carencias ahora que la izquierda estaba en el poder creaba presiones sobre el actuar gubernamental. Las serias dificultades fiscales encontradas, aunadas a la larga tendencia al crecimiento lento de la economía, agravada por la Gran Recesión, y las consecuencias de la falta de política monetaria a partir de la dolarización (que genera maneras de comportamiento en las acciones económicas del gobierno de las que no se hicieron cargo los dos gobiernos anteriores) impulsó a centrarse más en temas coyunturales que en las exigencias de entrar a visiones estructurales. La dependencia de votos de partidos de derecha, habituados a darle "gobernabilidad" a quien sea que gobierne, creaba obstáculos para obtener la aprobación legislativa a proyectos necesarios, dada la cerrada oposición de ARENA a toda iniciativa del Órgano Ejecutivo. La dificultad de encontrar en las gremiales empresariales una contraparte institucional abierta a entrar a fondo en el cambio de modelo, y el carácter de interlocutor privilegiado que se le dio al sector propietario de las actividades no transables - en buena medida por la presión de los Estados Unidos, dadas las contribuciones del Asocio para el Crecimiento - generó espacios poco adecuados para discusiones serias sobre los problemas fundamentales del crecimiento económico. Es decir, ni los espacios existieron, ni los esfuerzo por crearlos se hicieron en la forma requerida, ni se llegó a tener un plan de gobierno que se convirtiera en el norte y guía del equipo gobernante, pese a tener un documento elaborado con mucha seriedad académica.

La primera tarea que asumió el gobierno fue intentar paliar los efectos que sobre la vida de los ciudadanos más pobres tenía en ese momento la crisis económica de los Estados Unidos: descenso de nuestras exportaciones y de las remesas familiares que causaron una caída del PIB, además de que la reducción de estas últimas afectaba directamente la capacidad de compra de sus receptores. Las políticas de subsidios a los pobres que inició el gobierno anterior se revisaron, y se renovaron, cambiando conceptos y ampliando la naturaleza de las ayudas. En algunos casos el subsidio estaba ligado a la apertura de espacios productivos de la micro y la pequeña empresa, como fue el caso de la entrega de uniformes escolares. Se hizo efectiva la gratuidad de los servicios médicos en los centros públicos de atención, 
a la vez que se inició una ambiciosa reforma del sistema estatal de salud ${ }^{66}$. Se estableció un programa temporal de ocupación para los jóvenes de comunidades en situación de pobreza extrema. Estas acciones gubernamentales encontraron sus límites en la difícil situación de las finanzas públicas que se señaló en el acápite 4.1, a la vez que cargó con nuevas responsabilidades a un instrumento en situación precaria. Las respuestas que se dieron para obtener recursos fueron reformas puntuales, sin visión estructural, con un criterio - como hemos dicho que privilegia los problemas de caja sobre una visión con objetivos de mediano plazo, con todo que los primeros no pueden soslayarse.

Un cambio básico en la política económica fue la transformación de la asistencia a las microempresas y a las pequeñas empresas; los gobiernos de ARENA la concebían más como parte de la política social, como un paliativo temporal mientras llegaba el rápido crecimiento con alta generación de empleo por el que habían apostado al inicio. Se tomó en consideración la incapacidad para incrementar empleos en una economía con marcada tendencia al bajo crecimiento, además de los efectos de la decreciente necesidad de mano de obra por cada unidad producida debido a los avances tecnológicos; y, además se buscó aprovechar las potencialidades de incorporarse al tejido productivo del país que algunas actividades de estos sectores podían tener. La Comisión Nacional para la Micro y la Pequeña Empresa (CONAMYPE) comenzó a actuar con una visión más productiva, y a partir de ella impulsar los efectos sociales deseados. Se contó con la participación de universidades y organismos de la sociedad civil en centros de atención que han producido avances efectos positivos pese a las dificultades económicas. La nueva visión se plasmó en una ley en 2010; sin embargo, no es posible afirmar que se haya incorporado dentro de una visión estructurada de desarrollo económico y social.

Siguiendo la línea de hacer políticas sectoriales, que de alguna manera había comenzado en el gobierno de Saca, se establecieron conversaciones con la Asociación Salvadoreña de Industriales (ASI) para elaborar conjuntamente una política industrial; el documento concertado señalaba producciones con potencialidad de crecimiento, más allá de la manufactura por sub-contrato que es dominante en el sector, y con posibilidades de exportación tanto a Centroamérica como a terceros países. Terminada la política ${ }^{67}$ se procedió a iniciar su ejecución; hay que reconocer que la permanencia de un conjunto de disposiciones legales e institucionales que no se han alterado, además de la falta de definiciones para contrarrestar la tendencia a la prioridad de los no transables y de la maquila, dificultan la obtención de resultados superiores a los logrados, aunque éstos no son deleznables.

66. La reforma ha recibido reconocimientos de las instituciones internacionales del sector. Con realismo se debe reconocer que ha disminuido las carencias que existían al asumir el gobierno en 2009, sin haber logrado eliminarlas. Esto ha sido utilizado por la oposición de derecha y por los sindicatos del sector de salud para hacer críticas acerbas a la reforma.

67. El gobierno del Presidente Sánchez Cerén la revisó, y le dio más amplitud, convirtiéndola en Política de Transformación Productiva. 
A la par de esto, se continuó con la negociación de acuerdos comerciales, en especial el Acuerdo de Asociación de América Central con la Unión Europea. Es lamentable que una vez más se desperdician las ventajas obtenidas, dada las dificultades de la empresa productiva salvadoreña para responder a la demanda de nuevos mercados, más allá de los Estados Unidos y Centroamérica ${ }^{68}$. Como ha sido habitual, quien más ha utilizado la parte comercial del Acuerdo es la agroindustria azucarera.

En el área agrícola se descartó totalmente la idea de que el país debía abandonar la agricultura, como había comenzado a hacer el gobierno anterior. Se partió por racionalizar y transparentar la entrega de los subsidios a los pequeños productores de granos básicos, consistentes en la entrega de "paquetes agrícolas" conteniendo semilla mejorada y abono. Distribuido anteriormente a través de partidos de gobierno y sus aliados, se realizó un censo de productores que se incorporó a programas electrónicos, haciendo la entrega bajo estricto control de identificación del cultivador registrado. El sistema garantizó la utilización del subsidio para la producción, lo que hizo que ésta aumentara. Fue acompañado por un programa de agricultura familiar que busca integrar a la producción agrícola a familias en situación de pobreza a manera de satisfacer sus propias necesidades y a tener excedentes cuando existen las condiciones. Parecería que hay una carencia notable: una política más agresiva frente a las cooperativas de la reforma agraria, que poseen parte de las mejores tierras en forma comunal, las que habían sufrido una política de eliminación progresiva de parte de los gobiernos de ARENA; sus posibilidades de agro-industrialización no se han explotado debidamente, ni se han hecho los esfuerzos para impulsar una mayor capacidad de administración de las unidades. Hay avances paradigmáticos, muy puntuales, que no responden a una política estructurada en esta dirección.

El turismo recibió también un fuerte impulso. Si en el gobierno anterior el centro de los estímulos fiscales fue la gran empresa turística, ahora lo fue el pequeño empresario a través de respaldo técnico del gobierno, así como de la promoción de los destinos turísticos. Ha habido logros importantes, tanto en la utilización interna de estos servicios, como en la captación de turismo externo, pero aún lejos de la potencialidad que tiene este sector, según el mismo ministro de la cartera respectiva.

En el área de las obras públicas conviene resaltar la labor del ministerio. Si bien está sujeta a discusión la prioridad de ciertas grandes obras para el transporte de vehículos privados, es notoria su actividad en la construcción de protecciones a zonas en peligro por razones geológicas o climáticas, o en el mejoramiento de carreteras principales y secundarias. Y se ha ganado la opinión generalizada de haber combatido con éxito la tradicional corrupción de dicha cartera.

No es ésta una lista exhaustiva, sino ejemplos de lo realizado con la intención de 
moverse en otra dirección que la que se tenía en el pasado. Se han señalado arriba los obstáculos que a mi juicio han impedido cambiar sustancialmente el modelo. El conjunto de leyes e instituciones seguían, y siguen, sin cambios fundamentales. Se da estímulos fiscales a los mismos giros productivos que en el pasado, sin hacer un análisis del costo beneficio de ellos. Se sigue conversando primordialmente con quienes tienen sus principales intereses en los no transables, que - como decía Vidal en las citas que hemos hecho antes - ya era un serio problema veinte años atrás. La economía sigue teniendo una tendencia al bajo crecimiento, pese a los esfuerzos realizados, que se han mostrado muy limitados en sus efectos, y poco integrados en una visión estructural. En 2016 la economía creció un 2,5\%, según el Banco Central, el crecimiento más alto en casi una década; los impulsos son el consumo y el crecimiento de las remesas familiares, y los desequilibrios de la balanza comercial continúan siendo muy altos, indicando que se está lejos de superar los problemas centrales. Y, como veremos más adelante, las dificultades fiscales parecen haber llegado a una situación en la que las soluciones de caja, de visión de corto plazo, son más insuficientes que nunca. Todo dentro de las rigideces - difícilmente superables - de una economía dolarizada.

\section{La crisis de seguridad}

Al asumir el gobierno del Presidente Mauricio Funes, en el año 2009, la seguridad pública estaba viviendo un período de auge de los delitos de asesinatos y extorsiones. El país se contaba entre los más violentos del mundo, rondando los 60 asesinatos por cien mil habitantes cada año, seis veces lo que la Organización Mundial de la Salud considera una "epidemia". La política de "mano dura" del Presidente Flores, o la de "súper mano dura" de su sucesor, no habían revertido la criminalidad rampante; según las autoridades de seguridad pública, las pandillas llamadas "maras" tenían la responsabilidad de la mayoría de los hechos delictivos. Tampoco las acciones de prevención del Consejo de Seguridad Pública, creado por el Presidente Calderón Sol, habían dado resultado. El gobierno del FMLN entregó la conducción del ministerio de Justicia y Seguridad Pública a uno de sus principales dirigentes. Si al inicio pareció continuarse con las políticas del pasado, la falta de resultados fue respondida con la búsqueda de nuevas formas de acción frente al dramático problema del país. Se sustituyó al titular de la cartera por el ministro de Defensa; éste, siendo un coronel del ejército en condición de retiro, había respaldado la candidatura del Presidente Funes, y al nombrarlo en el gabinete había sido regresado al servicio activo, y ascendido a General. La visión de la nueva conducción fue la búsqueda de una tregua entre las dos principales pandillas del país, para reducir los asesinatos que se cometían en sus rencillas; esto, da la impresión ${ }^{69}$, se veía como parte de un escenario en el

69. La "tregua" se inició en el primer trimestre de 2012, poco antes de mi retiro del gobierno. Debo decir que en ningún momento se nos trasladó que era una política del gobierno, sino más bien una acción de las pandillas que el gobierno había "facilitado". Sin embargo, todo parece indicar que fue una iniciativa surgida del entorno personal del ministro, respaldada por el Presidente Funes. 
que se podía pasar a enfrentar los problemas de la extorsión ${ }^{70}$, y los asesinatos de personas que se niegan o no pueden pagar las cuotas exigidas por los "mareros", o que son víctimas por otras causas. Evidentemente, eso supuso privilegios diversos para los dirigentes de esas organizaciones criminales que guardaban prisión. Los asesinatos descendieron bruscamente, a menos de la mitad, dando un respiro a la población.

Sin embargo, el mal manejo de la información sobre la política que se ejecutaba terminó siendo el peor enemigo de la estrategia, si es que había alguna que fuera coherente. El ministro negaba que hubiera hecho acuerdos con los dirigentes pandilleros prisioneros para permitirles la relación con sus cuadros presentes en los territorios, así como que se les hubiera dado ventajas que no les correspondían de acuerdo a la ley. Alegaba que la tregua era entre pandillas y que el gobierno no había participado. A pesar de ello, se atribuía como éxito de su cartera la reducción de los asesinatos. Al final, teniendo que salir del ministerio por resolución de la Sala de lo Constitucional, lo hizo en pleno cuestionamiento de la estrategia, y con indicios de que las pandillas habían aprovechado la situación para aumentar su presencia en diversos territorios.

El gobierno de Sánchez Cerén entregó el ministerio a otro miembro de la dirección de su partido. El 29 de septiembre de 2014 inició labores el Consejo Nacional de Seguridad Ciudadana y Convivencia, con representación de partidos políticos, de la academia, de los concejos municipales, y de la sociedad civil, entre éstos distinguidos empresarios. Como resultado, se diseñó un plan llamado El Salvador Seguro que combina una alta dosis de acción punitiva frente al accionar de las "maras", con acciones preventivas a llevarse a cabo en conjunto con autoridades locales y con los ciudadanos de las comunidades escogidas. La "tregua" llegaba a su fin. Un aumento considerable de la violencia se dio de inmediato, así como enfrentamientos armados entre pandilleros y miembros de la policía nacional y elementos del ejército que los respaldan. La cifra de muertos diarios ascendió más allá de la veintena, llevando al país a la cifra de más de 100 asesinatos por 100.000 habitantes en 2015. Si bien la cifra ha registrado una notable reducción, la visión de los ciudadanos está dominada por una sensación de inseguridad y por la capacidad de los delincuentes para ejercer algún nivel de dominio sobre territorios determinados; para las autoridades de seguridad, la violencia que realizan contra los cuerpos de seguridad es una reacción a las pérdidas de control que están teniendo, dados los avances realizados en la reducción de la actividad criminal.

70. La extorsión, llamada "renta" en la jerga pandilleril, es una fuente primordial de ingresos para las pandillas. Toma diversas formas. Para forzar el pago, el recurso es la amenaza de la violencia, que en muchos casos se realiza. El asesinato es también una forma de eliminar a quienes se resisten a su presencia en las comunidades, y en no pocos casos a aquellos que no están dispuestos a incorporarse. 
La complejidad de este problema no ha recibido la atención adecuada de parte de quienes deberían aportar propuestas realizables. Contra una solución de corto plazo complotan la falta de tejido social de gran parte de la población, la marginación - en no pocos casos extrema - de amplios grupos de población, la falta de oportunidades para obtener ingresos pecuniarios en la vida legal, y el carácter mismo de la organización pandilleril; mientras tanto, la población, por razones de pura supervivencia, exige soluciones casi inmediatas. Y, por supuesto, un problema fruto de años de evolución, termina siendo percibido como responsabilidad exclusiva del gobierno de turno, lo que genera reacciones de los dirigentes del Estado a favor de acciones "efectistas", que no siempre son las más convenientes para encontrar el camino de solución. Y para la oposición es un flanco de ataque al gobierno, dirigido muchas veces por las mismas personas que condujeron las políticas fracasadas anteriores, sin explicar qué se hizo mal, y que se dejó de hacer, para que el problema creciera como lo ha hecho.

\section{El segundo gobierno del FMLN y la crisis fiscal}

En las elecciones de 2014 el FMLN ganó de nuevo la presidencia de la República. En la primera vuelta obtuvo el primer lugar por amplia mayoría, con ARENA como segundo; en el tercer lugar llegó el expresidente Saca, expulsado de este partido en 2009 , con mucho menos porcentaje de votación que el que se le auguraba, pero suficiente para obligar a una segunda vuelta. En ésta, un esfuerzo coordinado de la derecha empresarial y el partido ARENA hizo peligrar el triunfo de la llamada izquierda; sólo 6.000 votos separaron a Salvador Sánchez Cerén del candidato de la derecha, Norman Quijano. Con una personalidad con menos cualidades para presentarse mediáticamente que la que tenían sus dos inmediatos antecesores, también partía de un triunfo muy precario y con la responsabilidad de enfrentar circunstancias más problemáticas que las que Funes había encontrado. Con todo, éste sí iba a ser un gobierno conducido plenamente por el FMLN, aunque en busca de un mayor respaldo a su gestión incorporara algunos altos funcionarios provenientes de otros sectores.

El plan de gobierno que se ofreció a la población presentó como objetivos centrales lograr un país educado, productivo y seguro. Tres ejes que representan temas problemáticos, que tradicionalmente no han encontrado respuesta. En la práctica, la acción del gobierno se enmarcó en una línea básica de continuidad con la del gobierno anterior, con variaciones más marcadas en el área de la seguridad pública.

La economía ha aumentado su tasa de crecimiento, como se mencionó en el acápite anterior. Sin embargo, los problemas estructurales que impiden un aumento más elevado de la actividad económica, con sostenibilidad, no han sido abordados. Pese a ese logro, la precaria situación de las finanzas públicas pareció llegar a límites en los que la inveterada actitud de buscar paliativos en medidas 
de emergencia no lograba, ni siquiera, tirar hacia adelante el problema. Además, la discusión sobre el tema fiscal - sus dificultades y sus posibles soluciones ha mostrado que existe poca disposición para asumirlo con la seriedad y la responsabilidad necesarias, tanto de parte de las dirigencias políticas, como también de los llamados tanques de pensamiento y las gremiales empresariales. Y las condiciones se volvieron más difíciles a partir de procesos en la Sala de lo Constitucional que primero pospusieron, y luego eliminaron, medidas de emergencia para evitar caer en impago.

Las estimaciones de ingresos fiscales para 2016 fueron superiores a la recaudación obtenida, pese al aumento de la tasa de crecimiento. Mientras tanto los gastos del Estado siguieron al alza. Desde el principio del año se preveía la posibilidad de que el gobierno central no iba a poder cubrir sus compromisos, y que en el último trimestre del año la situación podía volverse muy crítica. La utilización de letras del tesoro del Gobierno de El Salvador (letes) ${ }^{71}$ crecía con una tendencia peligrosa. El año anterior, el gobierno central había encontrado un serio obstáculo para sanear su cartera de letes y obtener recursos para financiar el presupuesto. Con ese objetivo, el 23 de marzo del 2015 la Asamblea había aprobado la emisión de bonos por 900 millones de dólares, a ser vendidos en el mercado internacional; el partido ARENA votó en contra de la iniciativa del gobierno. La Sala de lo Constitucional de la Corte Suprema de Justicia decidió suspender la emisión por demanda de un ciudadano sobre supuestas violaciones a las regulaciones constitucionales en el proceso de aprobación; la sentencia declarando inconstitucional el decreto llegó hasta el 13 de julio de 2016, después de tensiones entre los órganos del Estado, y ásperas discusiones entre los partidos con representación legislativa.

En febrero de 2016 tres de los países que prestan más cooperación a El Salvador Alemania, España y Estados Unidos - y el Ministerio de Hacienda, presentaron un informe sobre la situación fiscal del país; éste había sido elaborado por el Instituto Centroamericano de Estudios Fiscales (ICEFI), a petición de la cooperación española, y lleva como título una frase muy sugerente: El Salvador: en la búsqueda de un acuerdo nacional de sostenibilidad fiscal. Se trataba de impulsar la concertación entre los actores políticos, y entre éstos y los dirigentes sociales, para encontrar salidas racionales y concertadas a un problema que estaba siendo tratado de manera muy poco adecuada.

71. Según la norma constitucional el endeudamiento soberano del Estado requiere de una votación de al menos los dos tercios de los diputados electos (64) para ser aprobados en la Asamblea Legislativa. Sin embargo, la misma norma primaria permite que el Órgano Ejecutivo adquiera deuda de corto plazo para suplir desequilibrios temporales de caja, a través de certificados - letras del tesoro del gobierno de El Salvador, llamadas letes - con plazos de redención no mayores de un año, y hasta un límite que señala la ley del presupuesto (en este momento es el $40 \%$ de los ingresos estimados). Ha sido un hábito que al acercarse al techo de endeudamiento, las letes sean canceladas a través de endeudamiento de largo plazo; esto a pesar de que parecería que contradice el carácter transitorio del desequilibrio, señalado por la Constitución como condición para su emisión. 
Por supuesto que las instituciones financieras internacionales ya estaban actuando sobre el tema. Tenían clara consciencia de que no se trataba de buscar medidas paliativas, sino de tomar decisiones que, a la vez que tuvieran efectos inmediatos sobre los problemas de liquidez, ayudaran a reducir las tendencias estructurales que ya hemos mencionado. Es evidente que sus propuestas parten de sus particulares puntos de vista.

En el estudio de INCEFI se afirma claramente cual es una de las causas principales - claramente no la única - de las condiciones deficitarias en las que funcionan las finanzas del gobierno: "Es pertinente recordar que la situación fiscal salvadoreña es sui generis, en el sentido de que gran parte del problema fiscal surgió a partir de la decisión de las autoridades públicas de absorber parcialmente el costo de la reforma previsional del pasado, y que a la fecha provoca el problema principal de la ejecución fiscal del país (aun cuando existen algunos gastos vinculados con subsidios que pueden ser optimizados)" (ICEFI [2015], p .19). Desde algún tiempo atrás, el Ministerio de Hacienda, con la cooperación del Banco Interamericano de Desarrollo, estaba trabajando en un estudio de reforma al sistema de pensiones a fin de aliviar la carga fiscal que éste representa. Las conclusiones recomiendan el tránsito hacia un sistema mixto: una parte de reparto hasta un determinado nivel de ingresos del cotizante, combinada con otra de ahorro privado para la parte que excede este monto, cuando ello ocurre. Eso permitiría al Estado no seguir en el ciclo de endeudamiento a través del Fideicomiso de Obligaciones Previsionales, que además se está acercado al porcentaje máximo sobre los fondos de pensiones que la ley permite.

Si con el empréstito se tuvo el obstáculo de la sentencia judicial, esta posibilidad de reforma se encontró con la resistencia de todos los partidos de la derecha, y con una campaña estridente de las gremiales de la empresa privada que la tildaron de ser "el robo del siglo". A lo que debe agregarse la poca habilidad del Órgano Ejecutivo para explicar y defender una reforma que se supone tiene una sólida base técnica, y un sustento de visión político-institucional. El proceso de reforma ha sido olvidado ${ }^{72}$, y el manejo de las cargas fiscales del sistema previsional sigue presentándose como ese factor de riesgo para la estabilidad fiscal que muchos hemos señalado por años, y que nos recuerda ICEFI en su estudio.

La segunda mitad del año 2016 ha estado cargada del tema de las finanzas públicas. En septiembre el Gobierno Central cumplió con la obligación constitucional de presentar su propuesta de presupuesto a la Asamblea Legislativa. Simultáneamente, el ministerio de Hacienda dio muestras clara de no tener los fondos para responder a sus compromisos financieros. Atrasos en los pagos a proveedores, posposición de transferencias señaladas en las leyes, dificultades para redimir certificados

72. Si no se reforma el sistema de pensiones, el porcentaje de endeudamiento del Fideicomiso de Obligaciones Previsionales con respecto al monto de los fondos de los cotizantes en posesión de las AFP superará el $45 \%$ a mediados de año, por lo cual esta forma de pago de las pensiones se habrá agotado. 
de deuda vencidos. Una situación de "emergencia fiscal" fue declarada por el Presidente de la República sin explicar cómo iba a enfrentarla, y sin asidero legal para acciones fuera de los cauces normales señalados por la ley. La reacción de las calificadoras de riesgo fue la degradación de la calificación de El Salvador a un rango que dificulta el acceso a los recursos externos.

El debate público ha sido en una tónica en la que la búsqueda de soluciones no ha sido el norte de los participantes. La oposición partidaria ha mantenido una actitud negativa frente a la situación, sin asumir la responsabilidad que significa que en la Asamblea Legislativa tenga la llave para paralizar o movilizar propuestas de solución. La crisis la atribuye al gasto dispendioso del gobierno y a la presentación de presupuestos mentirosos, elaborados a partir de supuestos que minimizan los gastos y aumentan artificialmente los ingresos; además, pide reducir los gastos del Estado a la vez que exige aumentar prestaciones y responsabilidades, y simultáneamente anuncia que no se aprobarán ni nuevos impuestos ni créditos externos ni votará por reformas que tienden a combatir la evasión fiscal. Y el gobierno, por su parte, con poca claridad en el discurso con el que intenta justificar sus propuestas.

El FMI ha intervenido con mucha intensidad buscando condiciones de diálogo, y ha llegado a elaborar un conjunto de propuestas para enfrentar el problema: reducir en 1,5\% del PIB los gastos del gobierno central, y aumentar en 1,5\% los ingresos. Lo primero con medidas de austeridad tradicionales; lo segundo con una serie de reformas impositivas: el incremento de $2 \%$ al IVA, el aumento de la tasa marginal de tributación para las más altas rentas, la aprobación de un impuesto a la propiedad, la revisión de los estímulos fiscales a determinadas actividades productoras de bienes y servicios ${ }^{73}$. Considerando la regresividad del IVA, recomienda tomar medidas para atender la situación de los más vulnerables. Todo esto en el marco de un acuerdo entre las distintas instancias partidarias que permitiera la suscripción de un acuerdo fiscal.

El diálogo entre partidos comenzó de una manera muy sui generis. Son los dos partidos mayoritarios los que se reúnen, teóricamente con la colaboración de los otros tres institutos políticos con representación legislativa. El primer fruto fue una Ley de Responsabilidad Fiscal para la Sostenibilidad Social, en la que, entre otras disposiciones, se establece: la obligación de reducir el endeudamiento del Estado en un mínimo del uno por ciento anual hasta llegar a 35\% (excluyendo la deuda que origina el sistema de pensiones, dice la ley); se exige un balance primario positivo, o al menos totalmente equilibrado, y se determinan plazos para la ejecución de las medidas para reducir el déficit fiscal; se establece el criterio de elaborar los presupuestos con visión trianual, aunque el correspondiente a

73. Algunas de la propuesta coinciden con las que se estaban discutiendo entre la oposición y el Ministro de Hacienda del presidente Saca al inicio de su período. El aumento del IVA no se había contemplado entonces. Véase acápite 4.1. 
cada año requerirá aprobación individual de acuerdo a la Constitución Política; se acuerda un aumento de la carga impositiva hasta el $17 \%$ del PIB. Sin embargo, los instrumentos concretos para lograr esos objetivos no han recibido el espacio de discusión que requieren.

La situación al terminar el 2016 es de suma gravedad. El entrampamiento del diálogo entre los dos grandes partidos no ha permitido aprobar el presupuesto del año 2017. Y de nuevo, la actitud de las dos partes no parece ser la más propicia para avanzar en acuerdos. Paralelamente el Ejecutivo ha tomado decisiones que han caldeado las relaciones con el sector privado, al aprobar aumentos a los salarios mínimos que habían sido rechazados por las gremiales.

La discusión del tema fiscal parece mostrar con meridiana claridad la poca disposición que los actores políticos y sociales tienen para llegar a acuerdos a partir de posiciones diversas. Más que diferir en propuestas lo que se hace es rechazar todo lo que venga del interlocutor, imposibilitando el diálogo. Y no pocas veces contradiciendo las mismas visiones políticas que proclaman defender. Una buena dosis de populismo ha dominado, en consonancia con las tendencias que en este momento se dan en muchos de los países más importantes.

\section{Las exigencias de una realidad transformada}

A lo largo de este trabajo se ha mencionado repetidas veces que la toma de medidas para corregir el rumbo del país se han ido posponiendo, buscando tirar hacia adelante los problemas, cuando no se han buscado medidas más mediáticas que efectivas para enfrentarlos. Paliar los síntomas sin combatir la enfermedad no ha sido una manera efectiva para evitar que la situación se agravara. Las sociedades no son estáticas; y la salvadoreña ha evolucionado a partir de dinámicas positivas y negativas. Ha sufrido transformaciones muy fuertes, a partir de cambios políticos, de alteraciones frecuentes de la estructura de la propiedad, de cambios bruscos en las relaciones familiares y en la estructura demográfica del país, etc. La dialéctica en la que se desarrollan estas transformaciones no ha sido adecuadamente asumida por los actores políticos y sociales, y tampoco ha contado con el debido aporte de la academia. La poca presencia de una visión de proceso para aprehender la génesis de la situación ha llevado a asumir visiones inmediatistas, en las que las cifras del presente son asumidas como "el problema", sin enfocarse en las causas.

En estas líneas finales se intenta hacer un ejercicio de ubicar las características relevantes de algunos de los aspectos de la vida nacional, y se señalarán los retos que representan. 


\section{Lo político-institucional}

De los elementos históricos que se han presentado anteriormente se puede concluir que, a juicio de quien esto escribe, la institucionalización de la democracia ha dado pasos innegables en el país. Los resultados electorales han sido respetados, los partidos políticos han actuado sin riesgos de ser perseguidos por sus opiniones, los ciudadanos han gozado de libertad para expresar sus ideas y para manifestarse. Como se ha mencionado, la alternancia acaecida en 2009 significó un momento de ruptura de las trabas que para el avance de ese proceso representaba la presencia de una forma patrimonialista de gobernar; si bien quien gobernaba gozaba del respaldo de la ciudadanía en las urnas, la forma que tomaba el manejo del aparato del Estado no permitía la autonomía que requieren sus órganos para funcionar en democracia. Las reglas de juego se transformaban a partir de un hecho no conocido desde los Acuerdos de Paz: El control y la manipulación de los tres órganos del Estado por ARENA (y los sectores sociales que son sus patrocinadores), con la cooperación negociada de otros partidos, parecía llegar a su fin; para aquellos que asumen la creencia en la democracia se generaba una oportunidad histórica que no debía desaprovecharse (Dada $\mathrm{H}$. [2015b]).

Como se ha dicho, los cambios requieren un proceso de adaptación de las instituciones, pero sobre todo de las personas encargadas de conducirlas. Los espacios de autonomía requieren responsabilidad en el ejercicio de los cargos, a la vez que aceptación de las inevitables divergencias que se pueden encontrar cuando se respeta la libertad de decisión. Más aún cuando el ambiente en que esto sucede está marcado más por la descalificación del que piensa diferente, en momentos en los que, lo que se necesita es una confrontación de ideas y visiones - aceptando la legitimidad de las diferencias - a partir de la cual se puedan encontrar compromisos.

No es discutible que la recién estrenada autonomía de los órganos estatales tuvo consecuencias positivas en la vivencia del estado de derecho; además de la contribución a la institucionalidad democrática, que en sí misma representa la ruptura con el sometimiento tradicional, varias de sus resoluciones representan avances efectivos. A su vez, generó, como se vio antes, conflictos entre los órganos del Estado, o con actores institucionales específicos (políticos y sociales) que, como es normal, trascendieron a los espacios públicos; varias sentencias de la Sala de lo Constitucional provocaron reacciones de aquellos que percibían que afectaban a sus intereses o sus atribuciones. Así mismo, surgieron críticas de quienes consideran que en varios casos carecen del sustento necesario para justificarlas, o que con ellas se han trascendido los límites de la interpretación constitucional al invadir funciones de otras instancias; en ocasiones parecen haber violentado el pacto político expresado en el texto constitucional, sin respetar los 
canales que la misma Constitución Política señala para su reforma ${ }^{74}$. Si bien las discrepancias han llevado a algunos a utilizar un tono exacerbado para expresarlas, y en más de un caso se han buscado atajos para dejarlas sin efecto, no es aceptable la afirmación de que discrepar con las sentencias de la Sala de lo Constitucional es reflejo del peligro en que está la institucionalidad democrática y el Estado de derecho; con renuencia o por coincidencia con ellas, han sido acatadas, aceptando el carácter de última instancia de dicho tribunal. Las discrepancias no han obstaculizado el cumplimiento de las sentencias.

Este proceso nos muestra claramente las carencias que aún tenemos en la vivencia de la democracia, que surgen tanto de la debilidad institucional todavía existente como de la dificultad de aceptar la legitimidad de las diferencias de opiniones e intereses, olvidando que la existencia de éstas es la que requiere de la democracia como el mejor método para procesarlas. La democracia demanda deliberación, discusión seria, y realmente política, de lo que es tan debatible como el grado de colaboración a la democratización que las sentencias constitucionales puedan proporcionar; deliberación que debe implicar la expresión de ideas y de conceptos, de análisis fundamentado sobre los alcances de lo aprobado y de la escuela de interpretación utilizada, de las visiones de cómo se construye democracia que tienen las distintas partes, etc.

La apertura de juicios contra la corrupción es también un factor positivo en nuestro tránsito hacia una democracia en la que las autoridades actúen con mayor transparencia y probidad. Sin antecedentes relevantes, las acciones del Órgano Judicial y del Ministerio Público han sacado a luz una realidad de nuestra vida en sociedad. No se trata sólo de funcionarios que aprovechan para su propio beneficio los fondos del Estado, sino que en diversos casos aparece la acusación de recibir fondos privados para favorecer a personas del sector privado, o empresarios que utilizaron su función pública para acrecentar su acumulación de riqueza. La ley de Información Pública se ha revelado como un instrumento eficaz.

La relación entre los distintos órganos del Estado se encuentra en una situación de transitoriedad. El FMLN, durante sus dos gobiernos, no ha obtenido una mayoría absoluta en la Asamblea Legislativa (43 de 84 diputados); la aprobación de sus propuestas ha dependido del respaldo de partidos menores que se proclaman de derecha, que en el pasado jugaban ese mismo papel en apoyo de los gobiernos de ARENA ${ }^{75}$. La propuesta de reforma al sistema de pensiones mostró las primeras señales de debilidad en los compromisos, y poco a poco el gobierno central ha visto reducidas sus posibilidades de hacer avanzar sus proyectos. La situación se ha vuelto precaria si se combina la carencia de mayoría calificada para aprobar créditos por la negativa de ARENA, con la imposibilidad de obtener mayoría

74. En diversas ocasiones he abordado este aspecto de nuestra realidad, tanto en exposiciones orales como en algunos escritos. Una síntesis de mi pensamiento está en un artículo publicado en dos partes por el periódico digital elfaro.net (Dada H. [2015b]).

75. Estos partidos justifican su comportamiento en lo que llaman "la necesidad de garantizar gobernabilidad". 
absoluta para la aprobación del presupuesto de 2017 por la renuencia de los partidos de derecha antes aliados. Esta precariedad parece presagiar obstáculos serios a la posibilidad de encontrar una salida a los problemas de liquidez y a la aprobación de una reforma integral de las finanzas públicas, y mucho más para hacer cambios en el modelo económico imperante.

Más allá de lo dicho, los retos que hay que superar son más profundos que los señalados. La consolidación de la institucionalidad democrática requiere que se resuelvan aspectos fundamentales de la concepción y de la práctica de la vida en democracia. Muchos de los problemas y los retos no son exclusivos de la situación salvadoreña, sino que se presentan aun en países con larga tradición democrática. A continuación intento mostrar algunos de ellos.

Desde las elecciones de 1994, la competencia partidaria ha estado centrada en dos grandes partidos que no nacieron para construir democracia. ARENA se creó con la promesa de restituir el autoritarismo militar-oligárquico, aunque proclamara adhesión a los principios de la democracia; su conversión en la expresión de una derecha empresarial neoliberal no fue acompañada de una transformación de su pensamiento y de su acción en lo que respecta a la institucionalidad democrática. El control de todos los órganos del Estado, y la posibilidad de utilizar patrimonialmente el aparato gubernamental, han dominado su práctica política. El FMLN surge de una lucha armada para instaurar la dictadura del proletariado. La realidad les ha impuesto restricciones a sus objetivos de poder; y más allá que eso, parece indicar que sus respectivas ideologías han agotado su pertinencia. Ninguno de ellos ha dado muestras de hacer una reflexión interna, en la que los ideales superados por la realidad se sustituyan por visiones conductoras, capaces de movilizar a sus estructuras, que vayan más allá de ejercicios de muy limitadas aperturas internas para la selección de sus dirigentes ${ }^{76}$. La carencia de un discurso renovado contribuye a explicar la prioridad que se da a la descalificación del otro sobre la discusión razonada de ideas divergentes.

Esto en un ambiente en el que la "anti-política" adquiere cada vez más popularidad en sectores de clase media. Comienza por definir la política de una manera restrictiva, enfocada más a la disputa entre partidos para lograr intereses personales que a su función de ser el espacio en el que se definen las maneras de convivir en el Estado. Se pretende que las soluciones a los problemas son exclusivamente técnicas, y que existe una única visión técnica que sea válida, que es la de los grupos dominantes. La misma militancia en partidos políticos es crecientemente considerada un motivo de descalificación acerca de la honestidad

\footnotetext{
76. El debate actual sobre el presupuesto es una muestra clara de lo que se afirma. ARENA habla por un lado de reducir el presupuesto - lógica de los ajustes neoliberales y de la visión de Estado mínimo - y por otro de mantener prestaciones e intervenciones del Estado que van en el sentido contrario. El FMLN asume la tarea de hacer el ajuste, con una visión poco estructural y sin correlacionar las acciones con los cambios a favor de las mayorías.
} 
y la capacidad de independencia de las personas ${ }^{77}$. Se va en una dirección de individualizar la representación política, de diluir el papel de los partidos como canales institucionales de representación que la Constitución Política les señala.

La "sociedad civil", en la que unos pocos ciudadanos pueden reunirse a nombre de un interés supuestamente colectivo, y pretender representar los intereses de la sociedad en su conjunto, es presentada como el espacio de la pureza y de la capacidad "técnica"; con un criterio más vanguardista que concertador, buscan caminos para sobrepasar el papel representativo que, pese a sus deficiencias, la población le ha dado a funcionarios escogidos en comicios cuyos resultados no están en discusión. Las deficiencias partidarias, y las acciones individuales de algunos de estos funcionarios, colaboran para darle aparente sustento a estas posiciones.

Varias de las resoluciones de la Sala de lo Constitucional están impregnadas de la visión señalada. Para convertirla en normas legales parten de una teoría de la interpretación de la Constitución Política que les permite trascender su tradicional función de "control negativo" del orden señalado en la carta magna, asumiendo en la práctica el papel de reales "legisladores positivos"78. Es de esta manera en la que fue violentado el acuerdo político que reformó en 1991 la Constitución de 1983 (véase acápite 2.1): un sistema político en el que los partidos estaban considerados como canales exclusivos de la representación ciudadana, creando un camino orgánico para la construcción de alternativas a ser consideradas por la población, fue alterado al hacer trascender la individualidad del voto a la individualidad de la representación; de la vigilancia orgánica de los procesos electorales por los partidos políticos se pasó a prohibir que sus militantes ejerzan esa función; se niega a los afiliados a partidos políticos la posibilidad de participar como candidatos en las elecciones de segundo grado.

No es relevante si uno está de acuerdo o no con las medidas impuestas por las sentencias. En ellas, se afirma, se parte "estrictamente de la ciencia jurídica", dejando de lado que, en democracia, la legislación es siempre un acuerdo político codificado; se toman decisiones a partir de visiones de la estructura democrática - por esencia, políticas - que se cubren con una justificación técnica insuficiente. $Y$ se cae en el riesgo de generar un autoritarismo ilustrado que puede poner en

77. Es evidente que no se pretende ignorar que los dirigentes políticos muchas veces actúan de manera que sirven para al menos explicar estas visiones. Lo que intentamos es señalar el peligro que éstas representan para la institucionalidad.

78. Los juristas llaman "control negativo del orden constitucional" a la atribución que tienen los tribunales constitucionales para declarar la nulidad de una ley que contraría el texto constitucional. La calidad de legislador positivo que asume en varias sentencias la Sala de lo Constitucional se expresa en decisiones que en el fondo alteran el texto de artículos de la constitución alegando incongruencia con otros que tienen prioridad sobre ellos, o sentencian que la Asamblea Legislativa debe legislar de una manera determinada en la sentencia. No intento discutir en el terreno de la ciencia jurídica, sino a partir de mi visión política, que me lleva a concebir el derecho como un acuerdo político codificado. 
riesgo la misma esencia de la democracia. El vanguardismo suele ser el mayor riesgo para la democracia.

Los retos a enfrentar en este terreno son múltiples. Los partidos deben asumir su responsabilidad de actualizar su pensamiento, y democratizar en serio - no cosméticamente - sus comportamientos internos. La ciudadanía debe asumir el carácter político de esta calidad, comprender que es en el compromiso de la acción política concreta que puede ir más allá de la crítica o de la riesgosa imposición de decisiones por vías que no son las constitucionales. Todos los ciudadanos debemos partir del rechazo de la peligrosa idea "pos-moderna" de que los problemas sociales tienen soluciones técnicas unívocas y no políticas. La única manera de rescatar la política es devolviéndole su auténtico sentido, dejando de lado la definición peyorativa que se le adjudica.

\section{La salida de la crisis fiscal}

En los capítulos anteriores se ha mostrado cómo la tendencia a desequilibrios fiscales ha sido una tendencia estructural de la economía salvadoreña; se ha señalado cómo la frecuente aprobación de pequeñas reformas puntuales a las leyes fiscales ha dado resultados insuficientes, acumulando las condiciones que en los últimos meses han mostrado todo su rigor. Dado el carácter de casi único instrumento de política económica que tienen las finanzas públicas, su debilidad se convierte en un factor que problematiza aún más la perspectiva de encontrar una salida a los entrampamientos que por largo tiempo ha sufrido la política económica. La carencia de moneda nacional, a su vez, genera rigideces a la economía, al mismo tiempo que exige comportamientos fiscales muy severos para coadyuvar a la estabilidad del sistema monetario dolarizado.

Los espacios de acción de la política fiscal son muy escasos. Los gastos están definidos previamente a la elaboración del presupuesto anual en un porcentaje cercano al 80\%: transferencias de los ingresos fiscales que por ley deben ser entregadas a diversas instancias del aparato del Estado, pago de las planillas de empleados, servicio de la deuda, etc. Además, debe tenerse presente la carga que para las finanzas públicas creó la manera en que se reformó el sistema de pensiones 20 años atrás. Sin embargo, el ICEFI afirma que "la principal rigidez (...) es la carencia de los recursos tributarios necesarios para enfrentar las necesidades de la población, por lo que en muchas oportunidades, el nivel de gasto que se requiere ejecutar para mejorar el bienestar y apalancar el crecimiento económico, excede los valores que podrían considerarse recomendables y han llevado a diferentes entes a proponer la implementación de reglas fiscales que limitarían el accionar de la política fiscal" (ICEFI, [2015]). La aprobación de una ley de responsabilidad fiscal a finales del año anterior ha incrementado esa rigidez, al obligar al gobierno central a cumplir metas de déficit primario y de endeudamiento sin existir disponibilidad de apoyar decisiones para analizar 
la estructura impositiva y los beneficios fiscales que establece la legislación actual. La situación se ha calificado de entrampamiento fiscal, tanto a partir de la imposibilidad de continuar con la situación presente como por la dificultad de llegar a acuerdos que construyan una salida estructural a un problema estructural.

En los capítulos anteriores se ha mostrado cómo la tendencia a desequilibrios fiscales ha sido una tendencia estructural de la economía salvadoreña; se ha señalado cómo la frecuente aprobación de pequeñas reformas puntuales a las leyes fiscales ha dado resultados insuficientes, acumulando las condiciones que en los últimos meses han mostrado todo su rigor. Dado el carácter de casi único instrumento de política económica que tienen las finanzas públicas, su debilidad se convierte en un factor que problematiza aún más la perspectiva de encontrar una salida a los entrampamientos que por largo tiempo ha sufrido la política económica; la ley de responsabilidad fiscal estrecha aún más el espacio de la política fiscal para impulsar el crecimiento. La carencia de moneda nacional, a su vez, genera rigideces a la economía, al mismo tiempo que exige comportamientos fiscales muy severos para coadyuvar a la estabilidad del sistema monetario dolarizado.

La discusión sobre este tema ha puesto a la luz del día todas las debilidades de las argumentaciones de los distintos sectores políticos, de las gremiales empresariales, y aun de algunos organismos académicos. Se afirma fácilmente que si se crece más y más sostenidamente no habría problema fiscal, pero no se dice una palabra de cómo es posible obtener lo que llaman "una tasa de crecimiento del PIB adecuada"; se exige un presupuesto balanceado, con disminución de gastos, a la vez que se condiciona su aprobación a la inclusión de privilegios sectoriales que significan aumentos de gastos; se rechaza toda reforma al sistema previsional, y simplemente se deja de lado que éste origina más de la mitad del déficit registrado en 2016; se exige balance primario "positivo o al menos equilibrado" con gastos acrecentados, y hay negativa a poner sobre la mesa la forma de percibir nuevos ingresos. Y el gobierno central continúa aferrado a un razonamiento en el que se presenta que el problema es la falta momentánea de liquidez; se reduce a demandar la aprobación de un presupuesto cuestionado, y a exigir la emisión de deuda pública (que no niego que es estrictamente necesaria), sin ir a los factores esenciales.

En toda esta ruidosa discusión parece haber un tema tabú: el costo fiscal que representan los beneficios impositivos para determinados giros empresariales. Los sectores más beneficiados son la maquila, determinados servicios, y el gran sector turístico; además de los espacios de elusión que, establecidas en las leyes, aprovechan los grupos empresariales más grandes y las altas rentas personales. Hay diversos cálculos sobre lo que representan con respecto a los ingresos fiscales percibidos; van de un 2,5 hasta un 3,5\% del PIB en tanto los ingresos rondan el 15\%. El ICEFI expresa al respecto de este tema: "Los tratamientos tributarios especiales, se estima que producen una erosión tributaria del orden del 3,4\% del $\mathrm{PIB}$, sin embargo, a pesar del otorgamiento de ventajas competitivas artificiales a 
sectores específicas, producir distorsión económica y generar competencia desleal entre sectores, no existe evidencia, por falta de estadísticas y controles, que permita fundamentar el hecho de que dichos tratamientos especiales hubiesen producido un incremento significativo del empleo (ICEFI [2015], Introducción)". Curiosamente, este tema no está siendo abordado - salvo contadas excepciones como la que aquí citamos - ni por el gobierno, ni por la oposición, ni por los centros de pensamiento económico; la carencia de ese análisis de costo beneficio que señala el ICEFI impide conocer si los beneficios que se conceden realmente se compensan con los resultados que se obtienen; a lo que habría que agregar que mientras no se determinen las apuestas estratégicas de la política económica no es posible juzgar si se está dando beneficios a sectores no prioritarios en desmedro de otros que sí lo son, o si los subsidios a las empresas están bien orientados.

El entrampamiento fiscal va teniendo serias consecuencias para el país. Ciertamente se ha dado en el año en el que más ha crecido la producción nacional desde 2007, lo que no evita visualizar sus efectos negativos sobre las perspectivas de la dinamización de la economía; y, más aún, para el combate a la pobreza, para la generación de condiciones de mayor equidad, para garantizar más y mejor educación, para reducir las condiciones de violencia social. Ya las pérdidas en la escala de calificación de riesgo que las calificadoras han hecho a lo largo de 2016 han colocado al país en condiciones muy desfavorables en el mercado financiero internacional, con consecuencias en el costo del dinero tanto para el sector privado como para el público.

La posibilidad de caer en "impago" de los compromisos del Estado es un riesgo que ha estado presente en los últimos meses de 2016; sin embrago, los dirigentes participantes en el diálogo, en el que deben construir respuestas, no parecen asumir la responsabilidad requerida. Si no se incluye la existencia de una economía dolarizada en el análisis de la realidad, ésta es percibida de forma incorrecta, y por lo tanto las soluciones que de allí surgen tienen una discutible pertinencia. Desde que salió al público la idea de abandonar la moneda nacional, diversos economistas expresamos que esa decisión - además de ser improcedente, e inconstitucional para algunos - generaba la necesidad de manejar las variables económicas de manera de no poner en peligro la sostenibilidad del nuevo sistema monetario. Sin embargo, el tema está notoriamente ausente en la mayoría de los análisis de la economía nacional, y en la presentación de las posiciones de los dirigentes sociales y políticos. Los riesgos de una inestabilidad monetaria no deben ser descartados, si las "soluciones" que se adopten surgen fundamentadas en los simplismos de la discusión presente.

La posibilidad de dar continuidad a las políticas sociales del gobierno también parece cuestionada, dada la manera en la que se está enfrentando el problema. Un país que ya tiene altos índices de inequidad y de pobreza, exige que cualquier 
solución no sólo sirva para cubrir las necesidades presupuestarias de los programas sociales, sino que sea un instrumento para corregir las inequidades de las leyes impositivas pensadas para favorecer la concentración de la riqueza, que se consideraba un pre-requisito para el crecimiento económico en el modelo agotado.

Y hay una pregunta que de alguna manera se ha planteado más de una vez en este texto: ¿Con qué instrumentos de política económica va a contar el Estado para poder impulsar el crecimiento económico y la distribución de los beneficios? Sin política monetaria, con una economía con alto grado de apertura al exterior, con un aparato estatal débil y poco funcional, parece que muy poco se puede hacer si no se dan cambios sustanciales en la visión y en el modelo ${ }^{79}$.

La intervención del FMI ha sido solicitada por la Secretaría Técnica de la Presidencia; la oposición política y la dirigencia gremial empresarial han respaldado su presencia. Relatamos en el acápite 4.6 cuáles han sido las propuestas del organismo. Para la oposición pareciera que lo único rescatable de las propuestas del organismo financiero internacional son las exigencias de reducción de gastos supuestamente superfluos, olvidando las sugerencias de elevación de impuestos al consumo y a las altas rentas personales, el restablecimiento del impuesto a la propiedad, así como la disminución de privilegios especiales en los contratos colectivos de los empleados públicos y en el trato a sectores productivos; y mucho menos acepta una reforma sustantiva al sistema previsional de ahorro privado. Curiosamente tampoco el gobierno, como se ha dicho, muestra convicción y energía en la defensas de sus propuestas anteriores, y no ha expresado posición sobre las reformas impositivas propuestas por el FMI, salvo que se niega a elevar la tasa del IVA.

El año 2017 es un año preelectoral. En el primer semestre de 2018 se elegirán los diputados y los concejos municipales, para entrar después a una dura disputa de la presidencia de la República que se decidirá en el primer trimestre de 2019. Para diversos analistas los partidos piensan más en los votos que pueden obtener que en la solución de los problemas. Es legítimo que los partidos cuiden su nicho electoral y que busquen acrecentarlo; pero la visión corta con la que lo hacen obstaculiza las soluciones. Si unimos esta corta visión electoral, con el objetivo de la derecha económica ${ }^{80}$ de retornar al gobierno a cualquier costo, encontraremos muchas dificultades para visualizar una concesión de espacios para la acción gubernamental. Por parte del FMLN se trata de limitar las afectaciones a los sectores cercanos a ellos, sin llegar a tomar decisiones necesarias que requieren conducción y liderazgo para tener acompañamiento de la población. ARENA, con su grupo parlamentario superior a un tercio de los diputados, tiene una situación

79. En el acápite 5.3 intentaré abordar este tema.

80. No es necesario reiterar que no es factible concebir una frontera entre la acción gremial empresarial y la acción política del partido de derecha: 
en la que en la práctica comparte la responsabilidad de gobernar; no basta que rechace las propuestas del gobierno, sino debe poner sobre la mesa una propuesta alternativa. El FMLN, con el ejecutivo en sus manos, tiene la primera responsabilidad en las decisiones de gobierno, la obligación de darle conducción al país, asumiendo las limitaciones que le imponen las condiciones políticas existentes, y su propia realidad interna. Sin embargo, ninguna de las dos partes parece estar dispuesta a asumir su correspondiente papel en el gobierno del país, ni menos en la seria reflexión política de la realidad nacional. El acuerdo fiscal ofrecido difícilmente va a responder a los requerimientos de la realidad.

\section{¿Qué hacer con un modelo agotado?}

La expresión más notoria de la situación’ económica es el llamado “entrampamiento fiscal" " Haber registrado un aumento del PIB superior a los obtenidos durante casi una década, ha permitido dejar parcialmente al costado del debate las deficiencias estructurales que condenan a esta economía a tener una expectativa de crecimiento muy baja, y a depender de impulsos al consumo como el principal factor de crecimiento de la producción de bienes y servicios.

La manera de hacer frente a las dificultades fiscales no es "neutra", o absolutamente técnica, como varios economistas y políticos pretenden ${ }^{82}$. Como se dice en la introducción, la economía es una ciencia social, y como tal sus académicos están adscritos a diversas escuelas, con explicaciones muchas veces diferentes sobre los mismos hechos, y con opiniones divergentes sobre la forma de enfrentar los problemas económicos. Por ejemplo, se dice que el IVA es un impuesto técnicamente fácil de cobrar, por lo que no hay que "politizar" el juicio rotundo de la técnica; pese a que es cierto que es fácil de cobrar, el juicio económico diferirá si quien lo hace pertenece a las escuelas económicas que privilegian el enfoque desde la oferta o si está adscrito a quienes se sitúan al lado de la demanda. Un impuesto elevado a los escalones más altos de las rentas personales puede ser juzgado por unos como un estímulo a la inversión, al encarecer los beneficios distribuidos por las empresas en relación con los mantenidos para ser dedicados a la acumulación; para otros, un factor generador de disminución de las expectativas para los potenciales inversores. Al final, el juicio político, a partir de las visiones diferentes

81. El 25 de noviembre de 2016, en un foro organizado por el Colegio de Profesionales en Ciencias Económicas (COLPROCE), hice una exposición titulada Las dificultades fiscales como problema estructural, en la que abordé este tema. El texto no ha sido publicado aún.

82. Hace algunas décadas esta visión de las ciencias sociales estaba presente en la mayoría de los diálogos entre profesionales de la ciencia económica. Ya Federico Engels había dicho que el marxismo es la única visión científica sobre los problemas de la sociedad, descalificando las visiones diferentes. Los neoliberales descartan la validez de otras escuelas económicas a nombre de una técnica unívoca, que supone que las "ideologías han muerto". No es cómodo sentirse obligado a rescatar lo que debiera estar implícito en los diálogos académicos; lo mismo sucede con la concepción de lo político, que para muchos se ha vuelto totalmente peyorativo. Es obvio que estas posturas, que coexisten en los mismos grupos, no son neutras, y tienden a fundamentar una tecnocracia que debe decidir a nombre de la sociedad en su conjunto a partir de un pensamiento dominante, y por supuesto de intereses muy concretos. 
que tienen los actores, es el que debe dirimir entre propuestas técnicas diversas, respetando los aportes que éstas proporcionan.

Más allá de lo dicho, toda política fiscal debe responder al modelo de acumulación establecido. La decisión de a quién y cómo cobrar, así como la determinación de en qué y cómo gastar o invertir, se supone que es coherente con el modelo ${ }^{83}$. Es decir, para concretar las medidas fiscales hay que tener como base un modelo definido; y, de nuevo, esta definición debe tener sustento técnico, a partir de la realidad que se desea superar. El Plan de Gobierno que presentó el FMLN durante la última campaña presidencial mostraba la voluntad de realizar algunas variaciones a las políticas económicas existentes, consolidando las que se habían iniciado en la administración de Funes. Pero, como se ha dicho, el conjunto de políticas, acciones y criterios institucionales, que conforman el modelo existente, han permanecido sin variaciones esenciales. Es más, pese a que el agotamiento del modelo heredado fue explícitamente aceptado por el gobierno anterior, ha habido dificultades para concretar las reformas necesarias. La carencia de nuevas apuestas estratégicas ${ }^{84}$ - que viene desde el gobierno de Antonio Saca es una muestra de la debilidad en la definición de un nuevo modelo.

A lo largo de los años se han planteado propuestas diversas, que no se han convertido en políticas definidas. La conversión del país en un centro logístico aprovechando su posición geográfica es la que por veinte años sigue presente sin definirse la manera de llevarla a la práctica. La construcción del puerto de la Integración Centroamericana era una pieza de esa política; sin embargo, las negociaciones y las decisiones políticas indispensables para su funcionamiento no fueron realizadas por los últimos dos gobiernos de ARENA - cuando había mejores condiciones para llevarlas a cabo - ni por los dos gobiernos del FMLN. No parece que las acciones de mejoramiento de algunas estructuras que formarían parte de esa política representen la asunción del "corredor logístico" como apuesta estratégica para el crecimiento económico del país.

La aprobación de un proyecto con la cooperación de la Cuenta del Milenio de los Estados Unidos, ha abierto la posibilidad de desarrollar inversiones en la franja costero-marítima del país. Las empresas a establecerse son sobre todo grandes empresas turísticas internacionales, que se espera puedan dinamizar la presencia de extranjeros en nuestras playas, además de generar mejores condiciones para los habitantes de la zona. Aún se diseñan los detalles del proyecto, que incluye una buena cantidad de obras públicas; a mi juicio debiera incorporar encadenamientos con productores de bienes y prestadores de servicios salvadoreños para poder interiorizar impulsos dinámicos a determinados sectores. Hay que tener presente que en materia impositiva las empresas que se establezcan gozarán de ventajas fiscales que reducen el impacto potencial sobre los ingresos fiscales de un crecimiento de la actividad turística.

83. La política fiscal establecida por el gobierno de Alfredo Cristiani era coherente con un modelo que concebía la concentración como prerrequisito del crecimiento, y al "derrame" de los beneficios como la forma de resolver las inequidades iniciales.

84. Recordemos que los anteriores gobiernos hicieron apuestas que no se ganaron. 
Cualquier política de crecimiento debe considerar la poca capacidad de la economía salvadoreña para generar oferta de empleos formales ${ }^{85}$. El tránsito de la concepción de la asistencia a las “mypes", realizado en el gobierno de Mauricio Funes (véase acápite 4.4), fue fruto de la convicción de que la gran empresa no tenía las condiciones de generar ocupación digna a una buena proporción de la población económicamente activa. Las mismas tendencias de las técnicas empresariales actuales y de las tecnologías en desarrollo conducen a una decreciente necesidad de mano de obra por unidad producida, y a la terciarización de actividades anteriormente ejecutadas al interior de la misma empresa. Cualquier modelo que se establezca supondrá actividades para estimular la capacidad de producción de pequeños empresarios, para apoyarlos en la búsqueda de demandas a satisfacer, y para contribuir a su asociación y a la generación de tejidos productivos locales. El argumento de que esto no es suficiente para hacer crecer la economía de manera "adecuada" no contradice su pertinencia para cubrir ese objetivo de generar ocupación digna y posibilidades de acumulación a la escala de la empresa, con las consecuencias positivas para el entorno.

Otro elemento central en cualquier decisión sobre políticas económicas debe ser el de las cooperativas surgidas de la reforma agraria realizada en 1980. Poseedoras de buena parte de las mejores tierras del país, han pasado de ser utilizadas en una política de guerra, a una decisión de deteriorarlas progresivamente, a una asistencia en su producción con características muy tradicionales; se requiere, en primer lugar, tratar a las cooperativas como lo que son: empresas de propiedad social, no movimientos sociales (sí lo es una federación de cooperativas). Su carencia mayor está en la capacidad administrativa. El Estado tiene instancias que podrían aliarse con ellas, o respaldar asociaciones con empresas privadas, para pasar de la producción primaria a una progresiva agro-industrialización, que aumentaría el valor agregado producido y produciría mayor estabilidad en su actividad económica.

La Política de Transformación Productiva es un aporte en el sentido correcto. Darle los recursos institucionales y financieros es un requisito necesario, aunque no suficiente, para que logre resultados. Los tratados comerciales abren espacios para encontrar nuevos mercados, pero es difícil que los empresarios, por sí mismos, tengan la capacidad de abrir los caminos de la exportación.

En todo caso, para reformar el modelo se requiere identificar las actividades a emprender, y también a los actores que pueden realizarlas. Esto, dado que no

85. Es frecuente que se consideren equivalentes las categorías de empleado formal con la de contribuyente a la seguridad social. Si todos los empleados inscritos en el sistema de seguridad social son formales, no todos los empleados formales pueden gozar de esta prestación. La ley no incluye a los trabajadores estrictamente agrícolas como potenciales inscritos en la seguridad social, ni tampoco a los que están en situación de prestadores de servicios por contrato, sin patrono ni empresa formal que les dé cobertura, pero que tienen formalidad jurídica en la realización de su trabajo. 
se trata de trascender un sistema de propiedad privada, en la que el Estado juega un papel de planificador indicativo e interviene en proporcionar estímulos a las actividades consideradas estratégicas. La construcción de alianzas se vuelve indispensable. Las alianzas privilegiadas deben ser con aquellos sectores empresariales que tienen sus intereses en la producción de bienes transables, dada la necesidad de disminuir el déficit de la balanza de bienes y servicios que desde tiempo atrás presenta la economía nacional. Por ejemplo, los empresarios con larga tradición de exportar a Centroamérica tienen una experiencia que debe servir de base para que se aventuren a nuevos mercados, como algunos ya lo hacen con mucho éxito.

La elite económica del país está encabezada por un pequeño grupo que tiene sus intereses fundamentales en actividades comerciales y de bienes raíces. Son a su vez los principales interlocutores del gobierno central, primordialmente en el seno del Consejo para el Crecimiento creado por un acuerdo con los Estados Unidos. El reto del gobierno de la República es ampliar los espacios de diálogo. $\mathrm{Ni}$ ellos ni las gremiales empresariales pueden pretender tener la representación de los intereses de muchos de los empresarios que se dedican a la producción. No se trata de descalificar a las gremiales, sino tener una idea realista de los límites de su capacidad de canalizar los requerimientos de inversores específicos.

Una deficiencia del FMLN es la debilidad de sus relaciones actuales con los sectores sociales. No se podrá salir de la presente situación sin exigir contribuciones de quienes son actualmente los privilegiados del funcionamiento de la economía y del Estado. La fuerza del gobierno la da en parte la institucionalidad del Estado que tiene en sus manos, pero se requiere de alianzas sociales que le den legitimidad a su acción. La derecha política, más que aliada de los más grandes poderes económicos es canalizadora de sus intereses; de allí extrae su mayor fuerza. La izquierda en el gobierno, si es verdaderamente una izquierda democrática con visión productiva y equitativa, requiere de sólidas alianzas que respalden un proyecto transformador. La necesaria renovación de los partidos políticos se vuelve aquí mucho más acuciante. Para una alianza en democracia con sectores sociales se necesita claridad de rumbo y capacidad de conducción.

Un acuerdo nacional para el crecimiento de la producción y el empleo es indispensable; su contenido dependerá de la capacidad de balancear los intereses divergentes de los distintos grupos ciudadanos, generando condiciones favorables a la producción, y generadoras de una distribución de beneficios más equitativa. Los profesionales de ciencias económicas debemos aportar nuestros conocimientos, sabiendo que la decisión final dependerá de los acuerdos políticos que los balances de las distintas fuerzas permitan, de las posibilidades reales de realización de los proyectos que se establezcan, y, por supuesto, de la calidad de los aportes y la claridad de visión de quienes lo conduzcan. 


\section{Una breve conclusión}

Este trabajo se finaliza a unos días de la celebración de los 25 años de los Acuerdos de Paz que se firmaron en el Castillo de Chapultepec. Una larga guerra civil había concluido. Las reformas político-institucionales que surgieron de las negociaciones han tenido un proceso de desarrollo que nos permite concluir que hemos avanzado. Los espacios para debatir los problemas nacionales están abiertos, la competencia por la conducción del gobierno no tiene restricciones ideológicas. Mucho camino queda aún por recorrer para generar condiciones equitativas para los partidos contendientes, lo que debe realizarse a partir de los avances alcanzados. Lo que puede constatarse es que pese a estos logros, los actores políticos y sociales aún tienen que interiorizar las exigencias de una sociedad democrática, y acomodar su pensamiento y sus acciones a las condiciones de la realidad actual.

Junto a esos avances, nos encontramos con un estancamiento económico de mediano plazo, que dificulta la respuesta a las demandas de empleo digno y de asistencia a las carencias de los sectores más desvalidos de la población. El reto principal es un acuerdo nacional para realizar las reformas necesarias a un modelo que se agotó antes de lograr resultados, y que en esencia continúa vigente. En este terreno, la deuda con la sociedad que tienen los dirigentes políticos y sociales es aún mayor que la mencionada anteriormente, de la misma dimensión que la que tiene una academia que no termina de cumplir su responsabilidad de dar análisis y propuestas para la consideración de los que constitucionalmente deben tomar las decisiones en el Estado.

La ciudadanía - al menos un sector de ella - utiliza ahora los instrumentos de información que antes fueron inexistentes; en este sector hay una creciente preocupación por la probidad y por el cumplimiento de las reglas de un Estado de derecho. Es notable que ahora participen de esta preocupación quienes se sentían muy cómodos en momentos en los que la autonomía de los órganos del Estado era prácticamente inexistente, y el ejercicio de la función pública se realizaba con mucha opacidad. Lamentablemente, esas energías se utilizan más en la necesaria crítica, y no se acompañan con la asunción de compromisos concretos en los espacios en los que la transformación del país se hace posible: la política, la verdadera política.

En este momento se habla de un acuerdo de segunda generación para enfrentar los problemas de ahora, que los acuerdos de Chapultepec no podían prever. Esto requerirá del esfuerzo de la ciudadanía, y en especial el de las dirigencias políticas y sociales, con la participación de los sectores académicos. Un reto fundamental a superar es la tergiversación de los conceptos, como se ha señalado en el texto. Más aún, cierta supeditación a las corrientes dominantes, que obstaculizan la expresión abierta del pensamiento de los ciudadanos; una cierta dosis de autocensura a falta de la tradicional censura represiva. El reconocido periodista estadounidense George Packer, al referirse a una situación similar que vive su 
país, expresa: “(...) de esta manera es que antes de hablar uno debe preguntarse: ¿Mi identidad me da el derecho de decir esto? (...) Esta atmósfera hace muy difícil tener conversaciones honestas, y da a un demagogo como Trump el aura de ser sincero. La 'autenticidad' que sus seguidores tanto admiran es realmente errónea y moralmente repulsiva. Pero cuando la gente de buena voluntad tiene temor de expresar argumentos legítimos los ilegítimos ganan fuerza" (Packer, [2016], p. $56)^{86}$. Estamos a tiempo para evitar llegar a tales extremos.

San Salvador, 9 de enero de 2017

\section{Bibliografía}

Acevedo, C. (2003), La experiencia de crecimiento económico en El Salvador en el siglo XX, Banco Interamericano de Desarrollo, 2003. Cristiani, A. (1992), Discurso del Presidente de El Salvador en la firma de los acuerdos de paz de Chapultepec, (recuperado electrónicamente).

Dada Hirezi, H. (1978), La economía de El Salvador y la Integración Centroamericana 1945-1960, San Salvador, UCA Editores.

-(2000), La desintegración del colón, elfaro.net.

(2013), Las apuestas perdidas, el faro.net.

(2015a), Picketty y la desigualdad: una visión desde El Salvador, Fundación Heinrich Böll.

(2015b), La defensa de la institucionalidad I y II, elfaro.net.

(2016), Twenty-Four Years Later, en ReVista (spring 2016),

Boston, Harvard University.

Estado de la Región (2016), Quinto informe. Estado de la región en desarrollo humano sostenible 2016, San José, Programa Estado de la Nación-Región.

FUSADES (1989), Hacia una economía de mercado en El Salvador: Bases para una nueva estrategia de desarrollo económico y social, San Salvador, FUSADES.

(2003), Estrategia económica y social 2004-2009, San Salvador, FUSADES.

ICEFI (2015), En la búsqueda de un acuerdo nacional de sostenibilidad, Guatemala, ICEFI.

Jerez, C. y Hernández Pico, J. (1973), El año político, San Salvador, UCA Editores.

López Bernal, C.G. (director) (2015), El Salvador, historia contemporánea, 
San Salvador, Fundación MAFRE-Universidad de El Salvador.

Packer, G. (2016), The Unconnected, en The New Yorker Oct. 31.

PNUD (2013), Informe de desarrollo humano El Salvador 2013. Imaginar un nuevo país. Hacerlo posible. Diagnóstico y propuesta, San Salvador, Programa de Naciones Unidas para el Desarrollo.

Rivera Campos, R. (2002), La economía salvadoreña al final del siglo: desafíos para el futuro, San Salvador, FLACSO El Salvador.

Vidal, J. H. (2010), De la ilusión al desencanto, San Salvador, Universidad Tecnológica de El Salvador.

Villiers-Negroponte, D. (2012), Seeking Peace in El Salvador, Nueva York, Palgrave-Mac Millan.

Torres Rivas, E. (2007) La piel de Centroamérica, San Salvador, FLACSO El Salvador.

Turcios, R, [1993] Autoritarismo y modernización, CONCULTURA, San Salvador. 